\title{
Article \\ Effector Profiles of Endophytic Fusarium Associated with Asymptomatic Banana (Musa sp.) Hosts
}

\author{
Elizabeth Czislowski (D, Isabel Zeil-Rolfe and Elizabeth A. B. Aitken* \\ School of Agriculture and Food Sciences, The University of Queensland, St. Lucia, QLD 4072, Australia; \\ elizabeth.czislowski@uqconnect.edu.au (E.C.); isabel.zeilrolfe@uq.net.au (I.Z.-R.) \\ * Correspondence: e.aitken@uq.edu.au
}

Citation: Czislowski, E.; Zeil-Rolfe, I.; Aitken, E.A.B. Effector Profiles of Endophytic Fusarium Associated with Asymptomatic Banana (Musa sp.) Hosts. Int. J. Mol. Sci. 2021, 22, 2508. https://doi.org/10.3390/ijms22052508

Academic Editor: Jan Schirawski

Received: 13 December 2020

Accepted: 26 February 2021

Published: 2 March 2021

Publisher's Note: MDPI stays neutral with regard to jurisdictional claims in published maps and institutional affiliations.

Copyright: (c) 2021 by the authors. Licensee MDPI, Basel, Switzerland. This article is an open access article distributed under the terms and conditions of the Creative Commons Attribution (CC BY) license (https:// creativecommons.org/licenses/by/ $4.0 /$ )

\begin{abstract}
During the infection of a host, plant pathogenic fungi secrete small proteins called effectors, which then modulate the defence response of the host. In the Fusarium oxysporum species complex (FOSC), the secreted in xylem (SIX) gene effectors are important for host-specific pathogenicity, and are also useful markers for identifying the various host-specific lineages. While the presence and diversity of the SIX genes has been explored in many of the pathogenic lineages of F. oxysporum, there is a limited understanding of these genes in non-pathogenic, endophytic isolates of F. oxysporum. In this study, universal primers for each of the known SIX genes are designed and used to screen a panel of endophytically-associated Fusarium species isolated from healthy, asymptomatic banana tissue. SIX gene orthologues are identified in the majority of the Fusarium isolates screened in this study. Furthermore, the SIX gene profiles of these endophytic isolates do not overlap with the SIX genes present in the pathogenic lineages of F. oxysporum that are assessed in this study. SIX gene orthologues have not been commonly identified in Fusarium species outside of the FOSC nor in non-pathogenic isolates of F. oxysporum. The results of this study indicate that the SIX gene effectors may be more broadly distributed throughout the Fusarium genus than previously thought. This has important implications for understanding the evolution of pathogenicity in the FOSC.
\end{abstract}

Keywords: effectors; SIX genes; endophytes; Fusarium

\section{Introduction}

Species within the Fusarium genus represent some of the most devastating and important pathogens of many of the world's agricultural crops. The Fusarium oxysporum species complex (FOSC) includes isolates that can be pathogens, saprophytes and even endophytes [1,2]. The plant pathogenic lineages of F. oxysporum have been recorded to cause vascular wilt in over 100 species of plants [3-5]. However, an individual pathogenic isolate of F. oxysporum is a specialist and typically causes disease in only one or two host species. As a consequence of this host-specificity, isolates of $F$. oxysporum are classified into special groups called 'formae speciales' (plural, ff. spp.; singular-forma speciaies, f. sp.) according to their specific host [1]. Many formae speciales consist of multiple, genetically distinct clonal lineages or vegetatively compatible groups (VCGs) [3,6,7].

Fusarium wilt of banana is one of the most notorious examples of disease caused by F. oxysporum and is also known as Panama disease of banana [8,9]. The isolates that cause Panama disease in banana have historically been referred to as F. oxysporum f. sp. cubense (Foc). However, recent taxonomic revisions within the FOSC have divided isolates of Foc into eight different species [10,11]. The relationship between these newly described species and other methods of describing and classifying isolates of Foc have been summarised in Table 1. For clarity of communication and consistency, the synonym Foc shall be used throughout this study to indicate all isolates and species within the FOSC that are pathogenic to bananas. This convention for the naming of isolates F. oxysporum shall also be extended to the other formae speciales that have also been recently epitypified [11]. Isolates within Foc are further classified into cultivar-specific races and VCGs 
(Table 1) $[3,6,7,12,13]$. Presently, tropical race 4 (TR4; VCG 01213/16) is of significant concern as it is highly pathogenic to all commercial cultivars and is rapidly spreading throughout the world's banana producing regions [14-18]. Phylogenetic analyses of the VCGs that comprise Foc have demonstrated that isolates within this forma specialis do not share a recent common ancestor and are commonly more closely related to isolates of $F$. oxysporum that are non-pathogenic or pathogenic to other host species [4,5,19-21]. It is hypothesised that the polyphyletic distribution of Foc in the FOSC is due to either convergent evolution and/or the horizontal transmission of the genes conferring host-specific pathogenicity. One such class of pathogenicity genes includes effectors.

Table 1. A summary of taxonomic species and other methods of developed to classify Fusarium oxysporum f.sp. cubense, including race and vegetative compatibility group (VCG) species designation within the Fusarium oxysoprum species complex (FOSC) [10,11,22].

\begin{tabular}{ccc}
\hline Race & VCG & Species Name within FOSC \\
\hline 1 & 0123 & Fusarium phialophorum \\
1 & 01210 & Fusarium purpurascens \\
1,2 & 0124 & Fusarium tardichlamydosporum \\
1,2 & 0125 & Fusarium tardichlamydosporum \\
1,2 & 0128 & Fusarium tardichlamydosporum \\
1, SR4 & 01220 & sp. (not determined) \\
2 & 01214 & Fusarium tardicrescens \\
R4 & 0121 & Fusarium odoratissimum \\
R4 & 0122 & Fusarium phialophorum \\
SR4 & 0120 & Fusarium phialophorum \\
SR4 & 0129 & Fusarium phialophorum \\
SR4 & 01211 & Fusarium phialophorum \\
SR4 & 0121 & Fusarium phialophorum \\
SR4 ${ }^{1}$ & Fusarium purpurascens \\
TR4 & 0126 & Fusarium odoratissimum \\
TR4 ${ }^{2}$ & 01213 & Fusarium odoratissimum \\
Undetermined & 01216 & Fusarium tardichlamydosporum \\
Undetermined & 01212 & Fusarium duoseptum \\
Undetermined & sp. (not determined) \\
Undetermined & 01217 & Fusarium phialophorum \\
Undetermined & 01218 & Fusarium grosmichelli \\
Undetermined & 01219 & Fusarium tardichlamydosporum \\
Undetermined & Fusarium duoseptum \\
Undetermined & Fusarium duoseptum \\
N/A ${ }^{3}$ & 01221 & N/A ${ }^{3}$ \\
\hline
\end{tabular}

${ }^{1}$ Previously considered race $1 .{ }^{2}$ Considered to be the same as VCG $01213 .{ }^{3}$ VCG 0127 is no longer considered to be valid (VCG of race 3 ).

Effector genes encode for small proteins that are secreted by plant pathogens, including F. oxysporum, during the infection of a host [23]. These proteins are often critical for infection as they manipulate the defence response of a host. In F. oxysporum, a family of effector genes termed secreted in xylem (SIX) genes have been identified [24]. Currently, 14 SIX genes have been experimentally identified in the tomato pathotype, F. oxysporum $\mathrm{f}$. sp. lycopersici (Fol) [24-28]. Subsequent to their discovery, SIX3, SIX4, SIX5 and SIX6 have been experimentally verified to be required for full virulence of $F$. oxysporum in its respective host [24,29-33]. Furthermore, studies in the tomato and cucurbits have demonstrated that the small, dispensable accessory chromosomes to which the SIX genes are localised can be horizontally transferred from pathogenic lineages of F. oxysporum to a genetically distinct, non-pathogenic isolate of F. oxysporum [33,34]. In both the tomato and cucurbit pathosystems, the transfer of accessory chromosomes from a pathogenic donor into a nonpathogenic recipient was accompanied by a gain of pathogenicity towards the respective host. These experiments have been important for demonstrating the significant impact 
these accessory chromosomes and associated pathogenicity genes have on the phenotype of their host strain.

Although 14 SIX genes have been described in the Fol lineages, not all 14 SIX genes are carried by other formae speciales [22,30,35-38]. In fact, van Dam et al. demonstrated that the formae speciales of $F$. oxysporum each harbour a unique combination of effectors. These effector profiles can be used to distinguish the different host-specific lineages [39]. Furthermore, variation in the SIX genes has been particularly useful for distinguishing different races and clonal lineages that exist within a forma specialis $[22,26,37,39,40]$. The unique combination of effectors has been proposed to confer the host-specific pathogenicity exhibited by plant pathogens, such as F. oxysporum. Several SIX genes, including SIX2 and SIX6, have been previously reported in other species of Fusarium, including F. verticillioides, F. proliferatum, F. foetens, F. hostae and F. agapanthi [36,41,42]. Homologues of SIX1 and SIX6 have also been described outside the Fusarium genus in Colletotrichum orbiculare and $C$. higginsianum, as well as SIX1 in Leptosphaeria maculans [43-45].

In Foc, homologues of SIX1 and SIX9 have been identified in all isolates of Foc, while SIX8 was only identified in the VCGs of race 4 of Foc $[22,35,46]$. The other SIX genes identified in Foc include SIX2, SIX6, SIX7, SIX10, SIX13 and a pseudogeneised homologue of SIX4 $[22,35,46]$. Specific homologues of the SIX genes were associated with the different races of Foc. Furthermore, Czislowski et al. demonstrated evidence of horizontal transfer of the SIX genes between the lineages of Foc [22]. Subsequently, it was hypothesised that the polyphyletic relationship of the Foc lineages can be attributed to the horizontal transference of effectors and pathogenicity genes, including the SIX genes [22]. Although the distribution and diversity of the SIX genes in the pathogenic lineages of Foc has been studied, less is known about the SIX genes in non-pathogenic lineages of F. oxysporum associated with banana and other healthy hosts.

There has been a strong emphasis on understanding the distribution and diversity of effectors in the plant pathogenic forms of F. oxysporum. Species of Fusarium are commonly isolated from the tissue of healthy, asymptomatic host plants, including banana [47-51]. For the purposes of this study, endophytically-associated non-pathogenic isolates are considered those that have been recovered from healthy, asymptotic host material. These isolates are to be considered non-pathogenic towards the host that they were recovered fromhowever, this should not automatically preclude them from possibly being pathogens of other hosts. The presence of effectors in non-pathogenic lineages of F. oxysporum is not as well understood. This is in part due to the difficulty in classifying an isolate of $F$. oxysporum as truly non-pathogenic. Although isolates of F. oxysporum are common in soil environments and in healthy, asymptomatic hosts, the classification of these isolates as truly non-pathogenic is practically impossible, due to the number of hosts that must be screened in pathogenicity assays [2]. The use of molecular methods to classify pathogenic lineages of F. oxysporum is further complicated by the polyphyletic nature of many of the formae speciales [5]. Therefore, the development of a molecular method that is capable of distinguishing pathogenic and non-pathogenic lineages of F. oxysporum is highly desirable. The majority of studies investigating the utility of the SIX genes for identifying and distinguishing lineages of F. oxysporum have predominantly focused on plant pathogenic formae speciales. Few studies have sought to better understand the frequency of SIX genes in isolates of F. oxysporum recovered from the soil of different ecological environments.

Isolates of $F$. oxysporum recovered from the rhizosphere or asymptomatic hosts have been shown to have a reduced number of effectors, including SIX genes. Rocha et al. identified SIX gene homologues in only $12 \%$ of F. oxysporum isolate recovered from the soil of native environments [52]. Inami et al. also screened isolates of F. oxysporum recovered from the soil or tissue of wild tomato species for the presence of SIX1, SIX3 and SIX4. However, they was unable to detect any of these genes in any of the isolates [49]. Jelinski et al. found that the SIX genes were more frequently identified in isolates of F. oxysporum recovered from the soil of a tomato field known to be affected by Fol [53]. The isolates were screened for SIX1-SIX7 and half of the isolates had the same SIX gene profile as Fol, 
while 3\% of the isolates carried a combination of SIX genes that was not typical of Fol. Interestingly, one isolate that harboured the same SIX genes as Fol was non-pathogenic towards susceptible tomato in a subsequent pot trial. There are limited studies that have investigated whether SIX genes are present in endophytic, non-pathogenic isolates of $F$. oxysporum recovered from the internal tissue of healthy, asymptomatic hosts. It is also unclear if other Fusarium species associated with the same ecological niche as F. oxysporum also harbour SIX genes. Furthermore, although Fusarium species are commonly recovered from the tissue of banana hosts, it is unclear how frequently SIX genes are associated with these isolates and if any of the SIX genes in the endophytic isolates are similar to those found in the pathogenic lineages of Foc.

This study sought to ascertain if isolates of Fusarium associated with healthy, asymptomatic banana plants also carried any SIX gene homologues, and if so, was there any similarities to the SIX genes known to occur in pathogenic lineages of Foc. Similar to what has been observed for non-pathogenic lineages of the FOSC other Fusarium species, it was hypothesised that the SIX genes would be infrequently associated with isolates of endophytic, non-pathogenic Fusarium from the tissue of asymptomatic banana hosts. It was hypothesised that of the non-pathogenic, endophytic isolates identified to carry SIX genes, their SIX gene profile would be distinct from the SIX gene profiles of the pathogenic lineages of Foc.

\section{Results}

\subsection{Universal Primers Successfully Detect SIX Genes in Pathogenic Formae Speciales}

To enable the identification of the SIX genes in isolates of F. oxysporum associated with healthy banana hosts, universal primers capable of amplifying each of the fourteen SIX genes were developed. A single set of universal primers capable of amplifying all known homologues of SIX9 could not be designed. The SIX9 homologues were separated into two groups (SIX9 (group 1) and SIX9 (group 2)), based on their \% identify to the Fol-SIX9 sequence (Figure S1). The ability of the universal primers to amplify their target SIX gene was determined by screening isolates of F. oxysporum $(n=46)$ representing nine different formae speciales, whose SIX genes profiles could also be investigated with whole-genome sequencing [22]. This included 25 isolates of Foc representing VCGs 012001223 and all known races of Foc. Where possible, the same isolate that was used in the whole-genome sequencing projects was screened with the SIX gene PCR primers. Where possible multiple isolates from the same forma specialis were also screened with the universal primers. It was not possible to screen the exact isolates of Fol and cotton-infection Fusarium oxysporum f.sp. vasinfectum (Fov), whose genomes have been assembled and made publicly available. In these instances, isolates from the same formae speciales held within the Brisbane Plant Pathology Herbarium (BRIP) were screened using the universal primers.

The performance of the primers was assessed by comparing the expected results from whole-genome sequencing to the amplicons produced by PCR using the universal primers. In the instances where the exact isolate used to generate whole-genome sequence information was screened by PCR, all primers produced SIX gene profiles identical to what was expected (Table 2). The isolate of Fol that was screened using the universal SIX gene primers was found to have an identical repertoire of SIX genes as predicted by the genome sequence data Fol-4287. However, the SIX gene profiles from the isolates of the cotton-infecting Fov that were screened in this study had several discrepancies with the SIX genes identified in the sequenced genome of Fov-NRRL25433. Firstly, although SIX14 was absent in the genome of Fov-NRRL25433, all of the Fov isolates screened in this study were shown to carry an orthologue of SIX14. Secondly, an orthologue of SIX9 (group 2) was identified in the genome of Fov-NRRL25543, yet was not detected by PCR in the isolates of Fov screened in this study. The distribution of SIX6, SIX8 and SIX11 was also shown to be present in the isolates of Fov included in this study, but absent in the reference Fov-NRRL25433 genome (Table 2). It has been previously established that Australian isolates of Fov are genetically distinct from other international isolates of Fov and 
have been hypothesised to have evolved within Australia from the endemic population of F. oxysporum [54]. Additionally, Chakrabarti et al. had previously demonstrated a difference in effector profiles between Australian and non-Australian lineages of Fov [55]. As a result, the differences in SIX gene profiles between the Australian Fov isolates screened by PCR and the reference genome of Fov-NRRL25433 was not unexpected. Therefore, the performance of the universal primers was determined to be satisfactory for identifying the SIX genes in the various formae speciales assessed in this study and proceeded to use the primers to screen isolates of Fusarium recovered from asymptomatic banana plants.

Table 2. A comparison of the secreted in xylem (SIX) gene profiles of the formae speciales in F. oxysporum by either querying reference genomes or screening by PCR with universal SIX gene primers developed for this study and confirmed by DNA sequencing.

\begin{tabular}{|c|c|c|c|c|c|c|c|c|c|c|c|c|c|c|c|c|}
\hline $\begin{array}{c}\text { Forma } \\
\text { Specialis }^{1} \\
\text { (Host Name) }^{1}\end{array}$ & Isolate $^{2}$ & SIX1 & SIX2 & SIX3 & SIX4 & SIX5 & SIX6 & SIX7 & SIX8 & $\begin{array}{l}\text { SIX9- } \\
\text { G1 }\end{array}$ & $\begin{array}{c}\text { SIX9- } \\
\text { G2 }\end{array}$ & SIX10 & SIX11 & SIX12 & SIX13 & SIX14 \\
\hline Fol (tomato) & $\begin{array}{c}4287 \\
\text { NRRL34936 }\end{array}$ & + & + & + & - & + & + & + & + & - & + & + & + & + & + & + \\
\hline Fol (tomato) & $\begin{array}{c}\text { MN25 } \\
\text { NRRL54003 }\end{array}$ & + & + & + & - & + & + & + & + & - & + & + & + & + & + & + \\
\hline Fol (tomato) & BRIP63541 & + & + & + & - & + & + & + & + & - & + & + & + & + & + & + \\
\hline $\begin{array}{c}\text { Fopf } \\
\text { (passionfruit) }\end{array}$ & BRIP28044 5 & - & - & - & - & - & + & - & + & - & + & - & + & - & - & - \\
\hline $\begin{array}{c}\text { Fopf } \\
\text { (passionfruit) }\end{array}$ & BRIP28044 & - & - & - & - & - & + & - & + & - & + & - & + & - & - & - \\
\hline $\begin{array}{c}\text { Fopf } \\
\text { (passionfruit) }\end{array}$ & BRIP5192 & - & - & - & - & - & + & - & + & - & + & - & + & - & - & - \\
\hline $\begin{array}{c}\text { Fon } \\
\text { (watermelon) }\end{array}$ & NT-DPI39655 & - & - & - & + & - & + & - & + & - & + & - & + & - & + & - \\
\hline $\begin{array}{c}\text { Fon } \\
\text { (watermelon) }\end{array}$ & BRIP5178 & - & - & - & - & - & + & - & + & - & + & - & + & - & + & - \\
\hline $\begin{array}{c}\text { Fon } \\
\text { (watermelon) }\end{array}$ & BRIP5177 & - & - & - & - & - & + & - & + & - & - & - & + & - & - & - \\
\hline $\begin{array}{c}\text { Fon } \\
\text { (watermelon) }\end{array}$ & BRIP5181 & - & - & - & + & - & + & - & + & - & + & - & + & - & + & - \\
\hline $\begin{array}{c}\text { Fon } \\
\text { (watermelon) }\end{array}$ & NT-DPI39655 & - & - & - & + & - & + & - & + & + & + & - & + & - & + & - \\
\hline Foz (ginger) & BRIP39299 4 & - & - & - & - & - & - & + & - & + & - & + & - & + & - & - \\
\hline Foz (ginger) & BRIP39299 & - & - & - & - & - & - & + & - & + & - & + & - & + & - & - \\
\hline Foz (ginger) & BRIP44986 & - & - & - & - & - & - & + & - & + & - & + & - & + & - & - \\
\hline $\begin{array}{c}\text { Fof } \\
\text { (strawberry) }\end{array}$ & BRIP53860 ${ }^{4}$ & + & - & - & - & - & - & - & - & - & - & - & - & - & + & - \\
\hline $\begin{array}{c}\text { Fof } \\
\text { (strawberry) }\end{array}$ & BRIP53860 & + & - & - & - & - & - & - & - & - & - & - & - & - & + & - \\
\hline $\begin{array}{c}\text { Fof } \\
\text { (strawberry) }\end{array}$ & BRIP62106 & + & - & - & - & - & - & - & - & - & - & - & - & - & + & - \\
\hline Fov (cotton) & NRRL25433 ${ }^{4}$ & - & - & - & - & - & - & - & - & - & + & - & - & - & + & - \\
\hline Fov (cotton) & BRIP63607 & - & - & - & - & - & + & - & - & - & - & - & + & - & + & + \\
\hline Fov (cotton) & BRIP43351 & - & - & - & - & - & + & - & - & - & - & - & + & - & + & + \\
\hline Fov (cotton) & BRIP25374 & - & - & - & - & - & + & - & - & - & - & - & + & - & + & + \\
\hline Fov (cotton) & BRIP43344 & - & - & - & - & - & + & - & - & - & - & - & + & - & + & + \\
\hline Fov (cotton) & BRIP43336 & - & - & - & - & - & + & - & - & - & - & - & + & - & + & + \\
\hline Fov (cotton) & BRIP43339 & - & - & - & - & - & + & - & - & - & - & - & + & - & + & + \\
\hline Fov (cotton) & BRIP43356 & - & - & - & - & - & + & - & - & - & - & - & + & - & + & + \\
\hline $\begin{array}{l}\text { Focg (Brassicae } \\
\text { family) }\end{array}$ & BRIP5176 ${ }^{4}$ & + & - & - & + & - & - & - & + & + & - & - & - & - & - & - \\
\hline $\begin{array}{l}\text { Focg (Brassicae } \\
\text { family) }\end{array}$ & BRIP5176 & + & - & - & + & - & - & - & + & + & - & - & - & - & - & - \\
\hline Fomg (alfalfa) & BRIP5189 4 & + & - & - & - & - & - & - & + & - & - & - & - & - & + & - \\
\hline Fomg (alfalfa) & BRIP5189 & + & - & - & - & - & - & - & + & - & - & - & - & - & + & - \\
\hline Foc (banana) & $\begin{array}{l}\text { BRIP62933 }{ }^{4} \\
\text { (VCG0124) }\end{array}$ & + & - & - & + & - & + & - & - & + & - & - & - & - & + & - \\
\hline Foc (banana) & $\begin{array}{l}\text { BRIP62933 } \\
\text { (VCG0124) }\end{array}$ & + & - & - & + & - & + & - & - & + & - & - & - & - & + & - \\
\hline Foc (banana) & $\begin{array}{l}\text { BRIP62895 } \\
\text { (VCG0123) }\end{array}$ & + & - & - & + & - & + & - & - & + & - & - & - & - & + & - \\
\hline Foc (banana) & $\begin{array}{l}\text { BRIP62895 } \\
\text { (VCG0123) }\end{array}$ & + & - & - & + & - & + & - & - & + & - & - & - & - & + & - \\
\hline Foc (banana) & $\begin{array}{l}\text { BRIP58698 } \\
\text { (VCG01217) }\end{array}$ & + & - & - & + & - & + & - & - & + & - & - & - & - & + & - \\
\hline Foc (banana) & $\begin{array}{l}\text { BRIP58698 } \\
\text { (VCG01217) }\end{array}$ & + & - & - & + & - & + & - & + & + & - & - & - & - & + & - \\
\hline Foc (banana) & $\begin{array}{l}\text { NRRL36116 } \\
\text { (VCG01223) }\end{array}$ & + & - & - & + & - & + & - & - & + & - & - & - & - & + & - \\
\hline
\end{tabular}


Table 2. Cont.

\begin{tabular}{|c|c|c|c|c|c|c|c|c|c|c|c|c|c|c|c|c|}
\hline $\begin{array}{c}\text { Forma } \\
\text { Specialis }^{1} \\
\text { (Host Name) }^{1}\end{array}$ & Isolate $^{2}$ & SIX1 & SIX2 & SIX3 & SIX4 & SIX5 & SIX 6 & SIX7 & SIX 8 & $\underset{\text { G1 }}{\text { SIX9- }}$ & $\begin{array}{c}\text { SIX9- } \\
\text { G2 }\end{array}$ & SIX10 & SIX11 & SIX12 & SIX13 & SIX14 \\
\hline Foc (banana) & $\begin{array}{l}\text { NRRL36116 } \\
\text { (VCG01223) }\end{array}$ & + & - & - & + & - & + & - & + & + & - & - & - & - & + & - \\
\hline Foc (banana) & $\begin{array}{c}\text { BRIP40340 } \\
\text { (VCG01213/16) }\end{array}$ & + & + & - & + & - & + & - & + & + & - & - & - & - & + & - \\
\hline Foc (banana) & $\begin{array}{c}\text { BRIP40340 } \\
\text { (VCG01213/16) }\end{array}$ & + & + & - & + & - & + & - & + & + & - & - & - & - & + & - \\
\hline Foc (banana) & $\begin{array}{l}\text { BRIP62962 } \\
\text { (VCG0121) }\end{array}$ & + & + & - & + & - & + & + & + & + & - & + & - & - & + & - \\
\hline Foc (banana) & $\begin{array}{l}\text { BRIP62962 } \\
\text { (VCG0121) }\end{array}$ & + & + & - & + & - & + & + & + & + & - & + & - & - & + & - \\
\hline Foc (banana) & $\begin{array}{l}\text { BRIP62892 } \\
\text { (VCG0122) }\end{array}$ & + & - & - & - & - & - & - & + & + & - & - & - & - & + & - \\
\hline Foc (banana) & $\begin{array}{l}\text { BRIP62892 } \\
\text { (VCG0122) }\end{array}$ & + & - & - & - & - & - & - & + & + & - & - & - & - & + & - \\
\hline Foc (banana) & $\begin{array}{c}\text { NRRL36118 } \\
\text { (VCG01221) }\end{array}$ & + & - & - & - & - & - & - & - & + & - & - & - & - & + & - \\
\hline Foc (banana) & $\begin{array}{l}\text { NRRL36118 } \\
\text { (VCG01221) }\end{array}$ & + & - & - & - & - & - & - & + & + & - & - & - & - & + & - \\
\hline Foc (banana) & $\begin{array}{l}\text { BRIP44012 } \\
\text { (VCG0120) }\end{array}$ & + & + & - & + & - & - & + & + & + & - & - & - & - & - & - \\
\hline Foc (banana) & $\begin{array}{l}\text { BRIP44012 } \\
\text { (VCG0120) }\end{array}$ & + & + & - & + & - & - & + & + & + & - & - & - & - & - & - \\
\hline Foc (banana) & $\begin{array}{l}\text { BRIP632594 } \\
\text { (VCG01218) }\end{array}$ & + & - & - & + & - & + & - & - & + & - & - & - & - & + & - \\
\hline Foc (banana) & $\begin{array}{l}\text { BRIP63259 } \\
\text { (VCG01218) }\end{array}$ & + & - & - & + & - & + & - & - & + & - & - & - & - & + & - \\
\hline Foc (banana) & $\begin{array}{c}\text { BRIP62779 } 4 \\
\text { (VCG01213/16) }\end{array}$ & + & + & - & + & - & + & - & + & + & - & - & - & - & + & - \\
\hline Foc (banana) & $\begin{array}{c}\text { BRIP62779 } \\
\text { (VCG01213/16) }\end{array}$ & + & + & - & + & - & + & - & + & + & - & - & - & - & + & - \\
\hline Foc (banana) & $\begin{array}{l}\text { BRIP39259 } \\
\text { (VCG01211) }\end{array}$ & + & + & - & + & - & - & + & + & + & - & - & - & - & - & - \\
\hline Foc (banana) & $\begin{array}{l}\text { BRIP39259 } \\
\text { (VCG01211) }\end{array}$ & + & + & - & + & - & - & + & + & + & - & - & - & - & - & - \\
\hline Foc (banana) & $\begin{array}{l}\text { NRRL25609 } \\
\text { (VCG01214) }\end{array}$ & + & - & - & - & - & - & - & - & + & - & - & - & - & + & - \\
\hline Foc (banana) & $\begin{array}{l}\text { NRRL25609 } \\
\text { (VCG01214) }\end{array}$ & + & - & - & - & - & - & - & - & + & - & - & - & - & + & - \\
\hline Foc (banana) & $\begin{array}{c}\text { NRRL26029 } \\
\text { (VCG01210) }\end{array}$ & + & + & - & + & - & + & - & - & + & - & - & - & - & + & - \\
\hline Foc (banana) & $\begin{array}{l}\text { NRRL26029 } \\
\text { (VCG01210) }\end{array}$ & + & + & - & + & - & + & - & - & + & - & - & - & - & + & - \\
\hline Foc (banana) & $\begin{array}{l}\text { BRIP62933 } \\
\text { (VCG0125) }\end{array}$ & + & - & - & + & - & + & - & - & + & - & - & - & - & + & - \\
\hline Foc (banana) & $\begin{array}{l}\text { BRIP62933 } \\
\text { (VCG0125) }\end{array}$ & + & - & - & + & - & + & - & - & + & - & - & - & - & + & - \\
\hline Foc (banana) & $\begin{array}{l}\text { BRIP59161 } \\
\text { (VCG0126) }\end{array}$ & + & + & - & + & - & - & + & + & + & - & - & - & - & - & - \\
\hline Foc (banana) & $\begin{array}{l}\text { BRIP59161 } \\
\text { (VCG0126) }\end{array}$ & + & + & - & + & - & - & + & + & + & - & - & - & - & - & - \\
\hline Foc (banana) & $\begin{array}{l}\text { BRIP22887 } \\
\text { (VCG0128) }\end{array}$ & + & - & - & + & - & + & - & - & + & - & - & - & - & - & - \\
\hline Foc (banana) & $\begin{array}{l}\text { BRIP22887 } \\
\text { (VCG0128) }\end{array}$ & + & - & - & + & - & + & - & - & + & - & - & - & - & - & - \\
\hline Foc (banana) & $\begin{array}{l}\text { BRIP40255 } \\
\text { (VCG0129) }\end{array}$ & + & + & - & + & - & - & + & + & + & - & - & - & - & - & - \\
\hline Foc (banana) & $\begin{array}{l}\text { BRIP40255 } \\
\text { (VCG0129) }\end{array}$ & + & + & - & + & - & - & + & + & + & - & - & - & - & - & - \\
\hline Foc (banana) & $\begin{array}{c}\text { NRRL36112 } \\
\text { (VCG01215) }\end{array}$ & + & + & - & + & - & - & + & + & + & - & - & - & - & - & - \\
\hline Foc (banana) & $\begin{array}{l}\text { NRRL36112 } \\
\text { (VCG01215) }\end{array}$ & + & + & - & + & - & - & + & + & + & - & - & - & - & - & - \\
\hline Foc (banana) & $\begin{array}{l}\text { BRIP59147 } \\
\text { (VCG01217) }\end{array}$ & + & - & - & + & - & + & - & - & + & - & - & - & - & + & - \\
\hline Foc (banana) & $\begin{array}{l}\text { BRIP59147 } \\
\text { (VCG01217) }\end{array}$ & + & - & - & + & - & + & - & - & + & - & - & - & - & + & - \\
\hline Foc (banana) & $\begin{array}{l}\text { BRIP58634 } \\
\text { (VCG01219) }\end{array}$ & + & + & - & + & - & - & + & + & + & - & - & - & - & - & - \\
\hline Foc (banana) & $\begin{array}{l}\text { BRIP58634 } \\
\text { (VCG01219) }\end{array}$ & + & + & - & + & - & - & + & + & + & - & - & - & - & - & - \\
\hline Foc (banana) & $\begin{array}{l}\text { BRIP58803 } \\
\text { (VCG01220) }\end{array}$ & + & - & - & + & - & + & - & - & + & - & - & - & - & + & - \\
\hline
\end{tabular}


Table 2. Cont.

\begin{tabular}{|c|c|c|c|c|c|c|c|c|c|c|c|c|c|c|c|c|}
\hline $\begin{array}{c}\text { Forma } \\
\text { Specialis } \\
\text { (Host Name) }^{1}\end{array}$ & Isolate $^{2}$ & SIX1 & SIX2 & SIX3 & SIX4 & SIX5 & SIX6 & SIX7 & SIX8 & $\begin{array}{c}\text { SIX9- } \\
\text { G1 }\end{array}$ & $\begin{array}{c}\text { SIX9- } \\
\text { G2 }\end{array}$ & SIX10 & SIX11 & SIX12 & SIX13 & SIX14 \\
\hline Foc (banana) & $\begin{array}{c}\text { BRIP58803 } \\
\text { (VCG01220) }\end{array}$ & + & - & - & + & - & + & - & - & + & - & - & - & - & + & - \\
\hline Foc (banana) & $\begin{array}{l}\text { BRIP59170 } \\
\text { (VCG01222) }\end{array}$ & + & - & - & - & - & - & - & - & + & - & - & - & - & + & - \\
\hline Foc (banana) & $\begin{array}{l}\text { BRIP59170 } \\
\text { (VCG01222) }\end{array}$ & + & - & - & - & - & - & - & - & + & - & - & - & - & + & - \\
\hline Foc (banana) & $\begin{array}{l}\text { BRIP62955 } \\
\text { (VCG01212) }\end{array}$ & + & - & - & + & - & + & - & - & + & - & - & - & - & + & - \\
\hline Foc (banana) & $\begin{array}{l}\text { BRIP62955 } \\
\text { (VCG01212) }\end{array}$ & + & - & - & + & - & + & - & - & + & - & - & - & - & + & - \\
\hline
\end{tabular}

${ }^{1}$ Fol—Fusarium oxysporum f.sp. lycopersici; Fopf-Fusarium oxysporum f.sp. passiflora; Fon—Fusarium oxysporum f.sp. niveum; Foz-Fusarium oxysporum f.sp. zingiberi; Fof-Fusarium oxysporum f.sp. fragariae; Fov-Fusarium oxysporum f.sp. vasinfectum; Focg-Fusarium oxysporum f.sp. conglutinans; Fomg-Fusarium oxysporum f.sp. medicaginis; Foc-Fusarium oxysporum f.sp. cubense. 2 NRRL_Agricultural Research Service Culture Collection, United States Department of Agriculture; BRIP—Brisbane Plant Pathology Herbarium; NT-DPI-Northern Territory Department of Primary Industries; VCG—vegetative compatibility group, as indicated next to isolates of Foc in parentheses. ${ }^{3}$ SIX9-G1-SIX9 group 1; SIX9-G2-SIX9 group 2. ${ }^{4}$ SIX gene profiles from these isolates were determined from whole-genome assemblies available on NCBI GenBank Genome database.

\subsection{A Genetically Diverse Range of Fusarium Is Associated with Healthy Banana Tissue}

To investigate the presence of SIX genes in endophytic Fusarium associated with banana, a collection of endophytic Fusarium species was generated by sampling and isolating 23 healthy, asymptomatic banana plants cultivated at two sites, Redlands (Queensland, Australia) and Mullumbimby (New South Wales, Australia). At both sites, plants with internal and external symptoms typical of Fusarium wilt were also identified and sampled ( $n=5$, Supplementary Table S1). Cultures derived from symptomatic plants were included in the subsequent analyses in parallel with the putatively endophytic cultures of Fusarium isolated from healthy, asymptomatic banana plants.

A total of 105 isolates of Fusarium were recovered from either root, pseudostem or peduncle tissue. Of these isolates, 25 cultures were derived from plants with internal and external symptoms of Fusarium wilt, while the remaining 80 cultures were isolated from healthy, asymptomatic hosts. From the Mullumbimby site, isolates within the FOSC and members of the Fusarium fujikuroi species complex (FFSC) were the most commonly isolated species identified by sequence analysis of the translation elongation factor 1-alpha (EF1- $\alpha)$ locus (Table 3). Isolates within the FOSC were frequently isolated from root tissue, while isolates of the FFSC were more commonly isolated from the pseudostem and peduncle tissue. Other species that were isolated from the Mullumbimby site included members of the F. solani species complex (FSSC) and F. incarnatum-equiseti species complex (FIESC). Similarly, from the Redlands site, isolates of the FOSC were also the most frequently isolated species and was more commonly isolated from root tissue (Table 3, Figure 1). A single isolate of both F. fujikuroi and F. solani were also recovered from plants grown at Redlands. A phylogenetic assessment of the genetic diversity of the Fusarium isolates was evaluated using the EF1- $\alpha$ sequence data.

Table 3. Summary of Fusarium species isolated from the tissue of banana plants cultivated at two sites in New South Wales and Queensland, Australia.

\begin{tabular}{|c|c|c|c|c|c|c|}
\hline \multirow{2}{*}{ Site } & \multirow{2}{*}{$\begin{array}{l}\text { No. of Plants } \\
\text { Sampled }\end{array}$} & \multirow{2}{*}{ Species Complex ${ }^{2}$} & \multicolumn{3}{|c|}{ Tissue Type } & \multirow{2}{*}{ Total } \\
\hline & & & Root & Pseudostem & Peduncle & \\
\hline \multirow{5}{*}{ Mullumbimby $\left(\mathrm{NSW}^{1}\right.$ ) } & 20 & FFSC & 0 & 16 & 14 & 30 \\
\hline & & FIESC & 2 & 2 & 0 & 4 \\
\hline & & FOSC & 17 & 8 & 9 & 34 \\
\hline & & FSSC & 3 & 3 & 3 & 9 \\
\hline & & TOTAL & 22 & 29 & 26 & 77 \\
\hline \multirow{5}{*}{ Redlands (QLD $\left.{ }^{1}\right)$} & 8 & FFSC & 0 & 1 & $\mathrm{~N} / \mathrm{A}$ & 1 \\
\hline & & FIESC & 0 & 0 & $\mathrm{~N} / \mathrm{A}$ & 0 \\
\hline & & FOSC & 17 & 10 & $\mathrm{~N} / \mathrm{A}$ & 27 \\
\hline & & FSSC & 0 & 0 & $\mathrm{~N} / \mathrm{A}$ & 0 \\
\hline & & TOTAL & 17 & 11 & $\mathrm{~N} / \mathrm{A}$ & 28 \\
\hline
\end{tabular}

${ }^{1}$ NSW-New South Wales, QLD—Queensland. ${ }^{2}$ FFSC—Fusarium fujikuroi species complex, FIESC—Fusarium incarnatum-equiseti species complex, FOSC—Fusarium oxysporum species complex, FSSC—Fusarium solani species complex. 

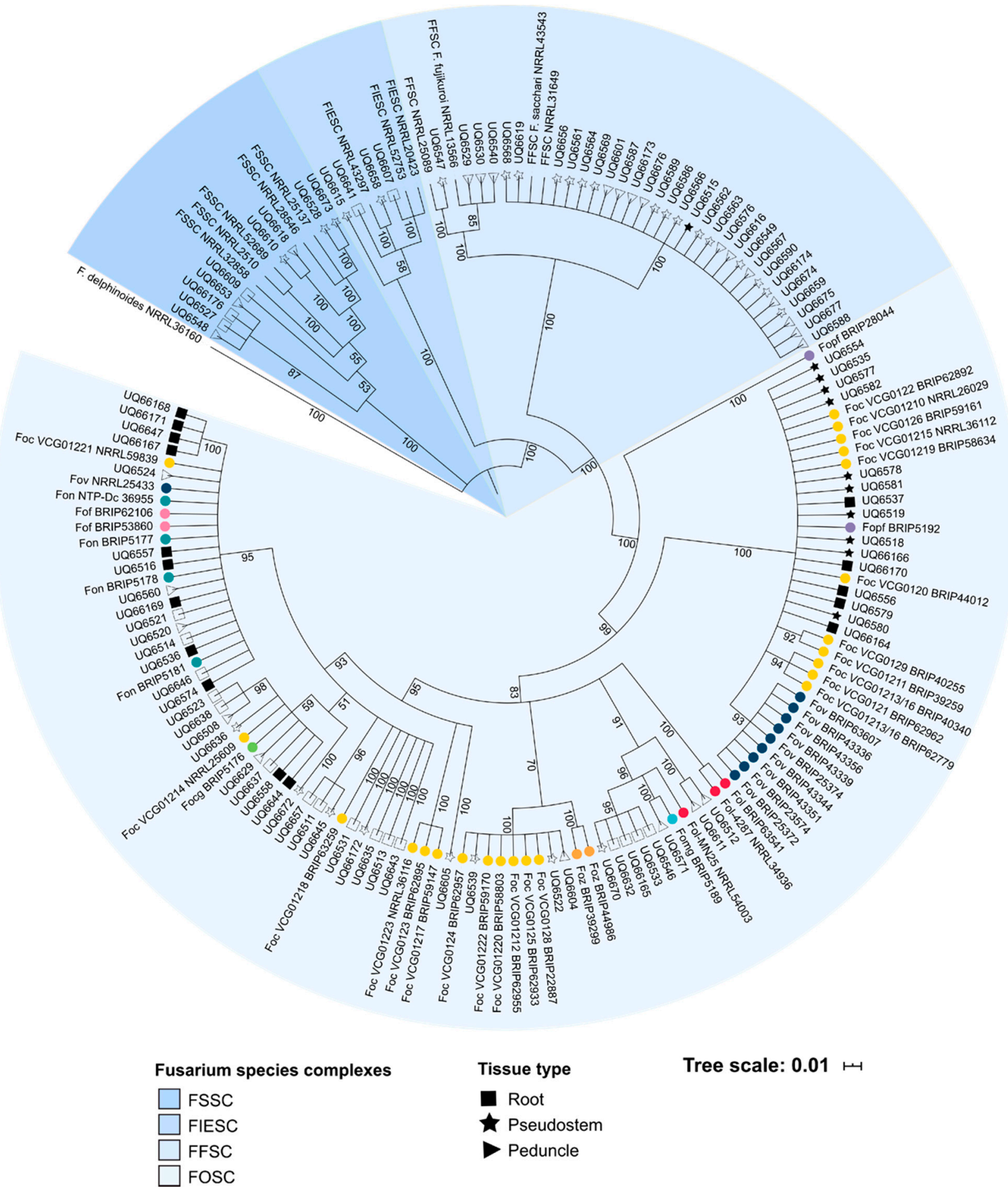

Tree scale: $0.01+1$

Figure 1. Phylogenetic tree of Fusarium isolates recovered in this study, reference sequences from pathogenic formae speciales of Fusarium oxysporum and other isolates from several Fusarium species complexes (FIESC_Fusarium incarnatum-equiseti species complex; FFSC_Fusarium fujikuroi species complex; FOSC_Fusarium oxysporum species complex; FSSC—Fusarium solani species complex). Pathogenic formae speciales of F. oxysporum are indicated with a coloured circle. The tissue from, which the isolates were recovered, is indicated by either a square (root), star (pseudostem) or triangle (peduncle). Isolates recovered from the Redlands site have a shaded shape. Isolates recovered from the Mullumbimby site have an unshaded shape. Nucleotide sequences from the translation elongation factor 1- $\alpha$ (EF1- $\alpha)$ locus were aligned and analysed using Bayesian inference. Branch labels indicate posterior probability determined during the analysis. 
A phylogenetic analysis was built from a $601 \mathrm{bp}$ alignment with $F$. delphiniodes used as an outgroup for the phylogeny. Trees produced from Bayesian and maximum likelihood analysis both produced trees with similar topologies (Figure S2). The four species complexes of Fusarium that were identified through morphological and sequence analysis were each recognised as unique clades in the phylogenetic tree (Figure 1). Isolates of the FOSC represented the largest and most diverse species complex in the phylogenetic tree. Within the FOSC, three sub-clades were identified. The majority of the endophytic isolates and pathogenic formae speciales of the FOSC clustered into clade A and clade B. All isolates of $F$. oxysporum recovered from the Mullumbimby site clustered into clade A of the FOSC. As has been previously reported for many pathogenic lineages of F. oxysporum, several of the formae speciales were found to be polyphyletic. The putatively endophytic isolates of $F$. oxysporum clustered with several of the pathogenic isolates of F. oxysporum, including F. oxysporum f.sp. medicaginis (Fomg), F. oxysporum f.sp. niveum (Fon), F. oxysporum f.sp. conglutinans (Focg) and various VCGs of Foc. Isolates of F. oxysporum isolated from both symptomatic and asymptomatic plants clustered with VCGs if Foc, such as VCG0120, VCG0124 and VCG01214 (Figure 1). None of the isolates of F. oxysporum recovered in this study clustered with the tropical race 4 VCG 01213/16. Within the FFSC, three species were identified; Fusarium sacchari, Fusarium proliferatum and Fusarium fujikuroi with F. sacchari being the most common species. Interestingly, the isolates of $F$. sacchari recovered in this study and one reference sequence of $F$. sacchari were all placed into a single clade indicating a low degree of genetic diversity in these isolates (Figure 1). Several well-supported lineages were identified in the endophytes from the FIESC and FSSC. There did not seem to be any strong correlation between the genetic lineages of Fusarium identified from the analysis of the EF1- $\alpha$ and the tissue type from which the endophytes were isolated.

\subsection{A High Proportion of Endophytic Fusarium Carry SIX Gene Orthologues}

The assessment of the endophytic Fusarium for SIX genes showed that a high proportion of the isolates harboured one of more of the SIX genes. The PCR screens with the universal primers found that $~ 75 \%$ of isolates from Mullumbimby and $82 \%$ of the isolates recovered from Redlands were found to have one or more of the SIX genes (Table 3, Figure 2). Twentyfour of the endophytic Fusarium isolates (representing 23\%) did not carry any SIX genes as while the rest of the isolates had between one and seven SIX genes (Figure 1). The most commonly identified SIX genes in the endophytic Fusarium sp. Were SIX4, SIX7, SIX1, SIX2 and SIX9 (group 1) (Figure 2). Orthologues of SIX3, SIX5, SIX9 (group 2) and SIX11 were not identified in any of the endophytic isolates. 


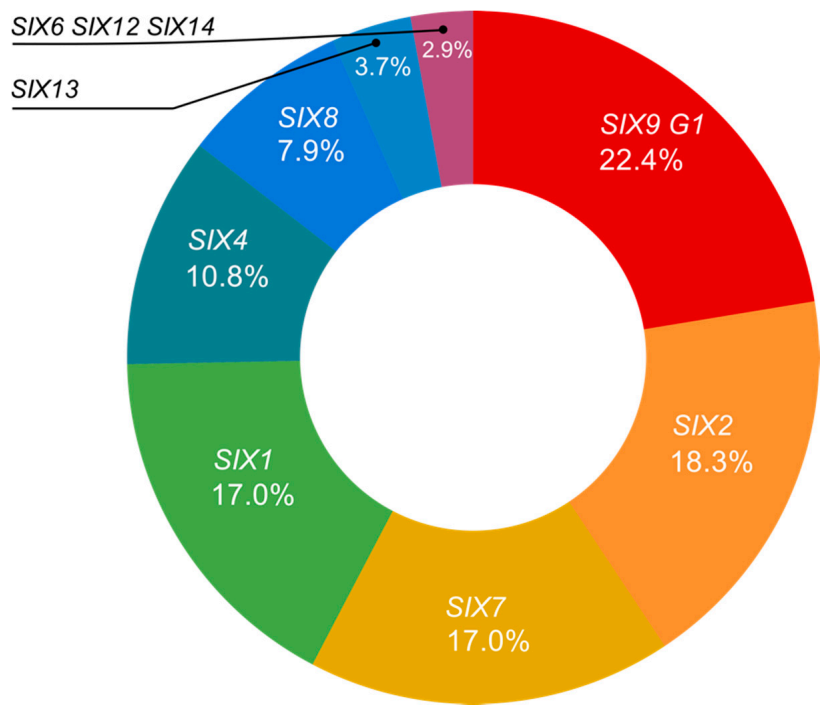

(a)

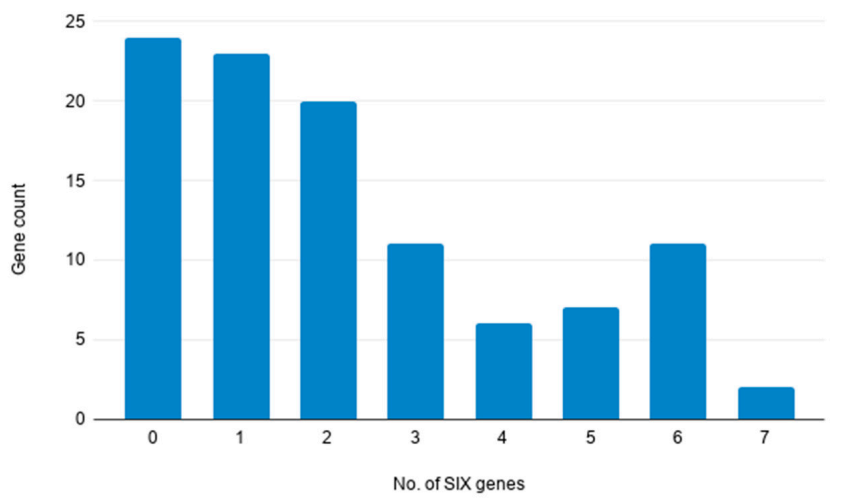

(b)

Figure 2. Summary of secreted in xylem (SIX) gene presence in isolates of Fusarium isolated in this study. (a) Frequency of SIX gene presence in isolates of Fusarium recovered from the tissue of field banana plants. (b) Summary of the number of SIX genes identified in isolates of Fusarium associated with healthy, asymptomatic banana plants.

\subsection{Hierarchical Clustering Distinguishes Pathogenic and Non-Pathogenic Lineages of Fusarium}

Prior to assessing the clustering patterns of the SIX gene profiles of the endophytic Fusarium, it was first determined whether the pathogenic formae speciales of F. oxysporum used in this study could be distinguished by their SIX gene profiles. A hierarchical cluster analysis, based on SIX gene presence/absence, showed that each of the formae speciales of $F$. oxysporum was distinguished from each other (Figure 3). Generally, isolates from the same forma specialis clustered together in a single clade, except for Fov and Foc. The Australian isolates of Fov were shown to form a single clade, however, this clade was distinct from the reference isolate of Fov, which was isolated from diseased cotton in China (Figure 3). While the SIX gene profiles of Foc was generally able to cluster lineages based on their cultivarspecific pathogenicity, the relationships between the lineages did not reflect the races of the Foc isolates. The SIX gene profile of VCG 01210 was shown to cluster more closely to the VCGs of tropical race 4, due to the presence of SIX2 in this VCG. The VCGs 01214, 01221,01222 and 0122 also did not cluster discretely with any of the clades representing race 1, race 2, subtropical or tropical race 4 VCGs. All of these VCGs were shown to have a reduced number of SIX genes in their profile. The hierarchical cluster analysis of the formae speciales of F. oxysporum demonstrated the utility of SIX gene presence/absence for distinguishing the various pathogenic lineages. The SIX gene profiles of the endophytic Fusarium were then incorporated into the hierarchical cluster analysis. 


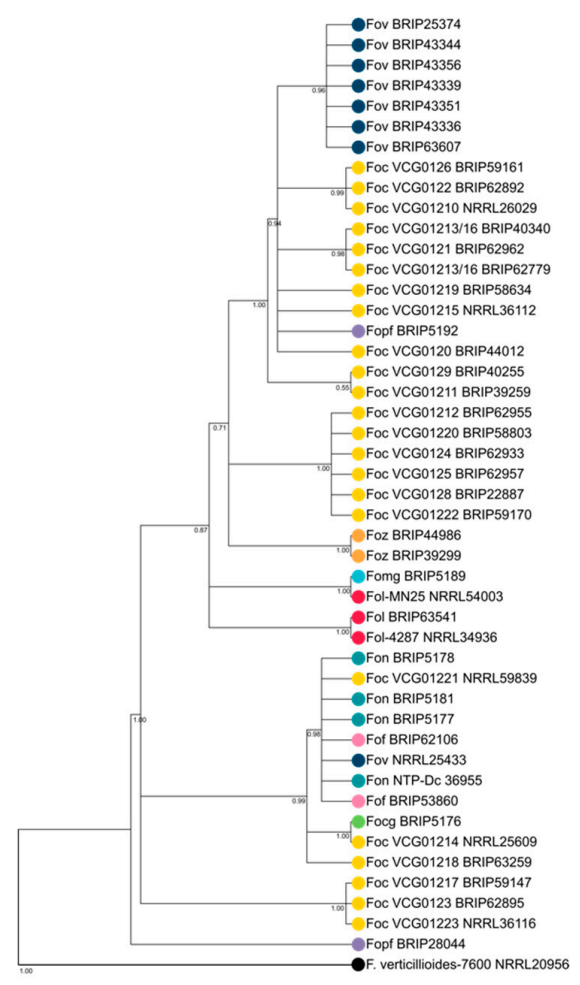

(a)

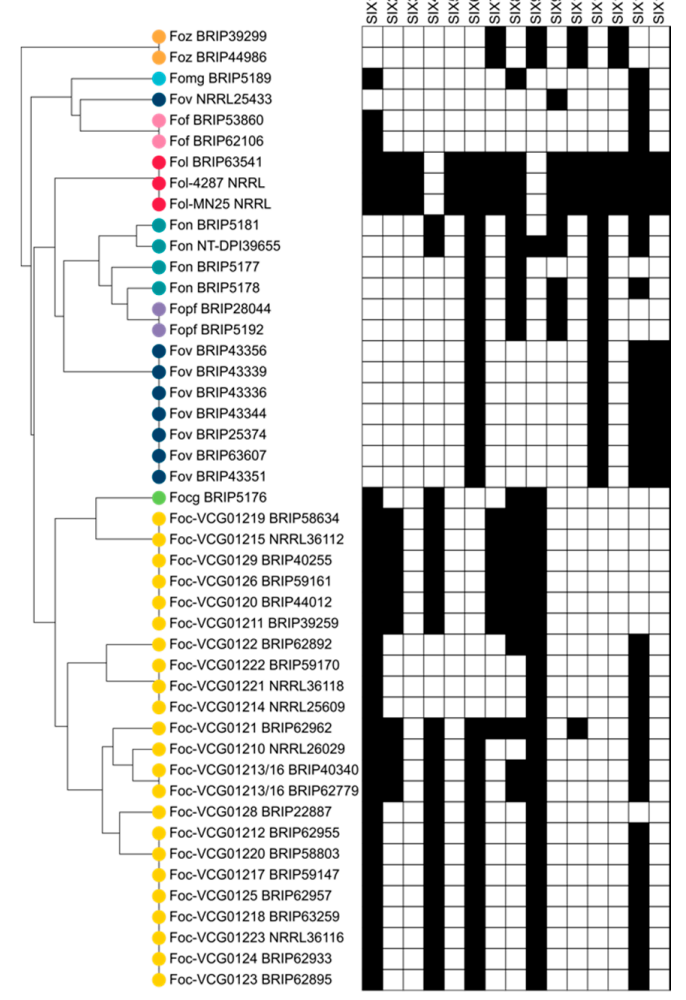

(b)

Figure 3. Hierarchical clustering analysis of the presence/absence of secreted in xylem (SIX) genes demonstrates a better association with the formae speciales of Fusarium oxysporum as compared to conventional phylogenetic analyses. (a) Genetic relationships of plant pathogenic formae speciales of F. oxysporum determined from an alignment and Bayesian analysis of the translation elongation factor 1- $\alpha(E F 1-\alpha)$. (b) Hierarchical clustering was used to analyse the SIX gene presence/absence matrix and generate a cluster dendogram for the formae speciales of F. oxysporum. The SIX gene presence/absence matrix used for the cluster analysis is given adjacent to the cluster dendrogram. A solid block indicates gene presence and a blank block indicates gene absence. Pathogenic formae speciales of F. oxysporum are indicated with a coloured circle.

A hierarchical cluster analysis was used to assess and group the phyletic patterns of the SIX genes identified in the pathogenic formae speciales of F. oxysporum and the isolates of Fusarium recovered from banana in this study. The cluster analysis showed that the putatively endophytic isolates of Fusarium recovered from asymptomatic, healthy hosts had a SIX gene profile that was distinct from the pathogenic formae speciales of F. oxysporum (Figure 4). Several formae speciales clustered closely with some of the endophytic Fusarium isolates. Seven isolates of Fusarium formed a sister branch to Foz, due to the presence of SIX7. Several putatively endophytic Fusarium isolates were also shown to cluster with Focg and several VCGs of Foc. Eleven isolates of F. oxysporum recovered from symptomatic plants at the Redlands site were shown to have SIX gene profiles that were identical to subtropical race 4 of Foc (e.g., VCG 0120) and three isolates recovered from symptomatic plants at the Mullumbimby site were shown to have the same SIX gene profile of race $1 /$ race 2 of Foc (Figure 4). These isolates also clustered in the same clade as the isolates of either subtropical race 4 or race 1 / race 2 , respectively, in the $E F 1$ - $\alpha$-based phylogeny. Due to the presence of external and internal symptoms of Fusarium wilt and the clustering of the isolates with pathogenic VCGs in both the EF1- $\alpha$ and SIX gene analysis, it was concluded that both Foc was present at both sites. Interestingly, the different species of Fusarium did not cluster into a single clade, but were instead dispersed throughout the different clades. Additionally, there did not seem to be any strong correlation between any of the SIX gene profiles of the endophytes and the tissue type or plant from which the endophytes were isolated from. Additionally, there are many examples throughout 
the dendrogram, demonstrating that endophytes from the two different sites shared an identical SIX gene profile.
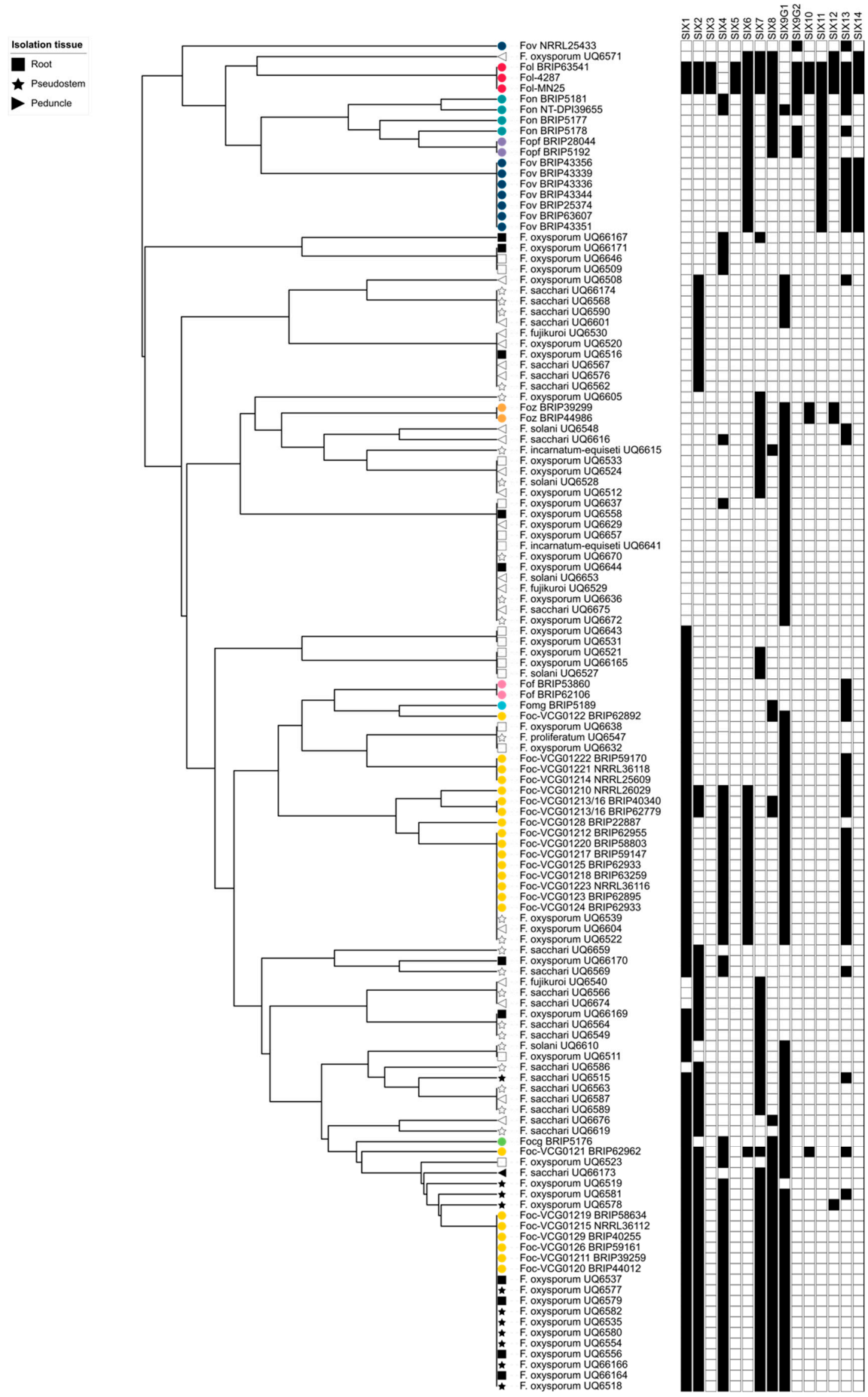

Tree scale: $0.01 \mathrm{H}$

Figure 4. Hierarchical clustering of plant pathogenic formae speciales of F. oxysporum and Fusarium isolated from banana tissue in this study. The secreted in xylem (SIX) gene presence/absence matrix used for the cluster analysis is given adjacent to the cluster dendrogram in which a solid block indicates gene presence and a blank block indicates gene absence. Pathogenic formae speciales of F. oxysporum are indicated with a coloured circle. The tissue, from which the Fusarium isolates were recovered, is indicated by either a square (root), star (pseudostem) or triangle (peduncle). Isolates recovered from the Redlands site have a shaded shape. Isolates recovered from the Mullumbimby site have an unshaded shape. 


\section{Discussion}

Plant pathogenic lineages of F. oxysporum, such as the banana pathogen Foc, represent a small fraction of the genetic diversity of the FOSC; many isolates exist in the rhizosphere as saprophytes whilst others can establish an endophytic, asymptomatic relationship with a host plant [2]. The distribution, diversity and evolution of effectors in the pathogenic lineages within the FOSC has been well-studied. However, the presence of effectors, such as the SIX genes, in putatively endophytic F. oxysporum is poorly understood.

Initially, this study hypothesised that isolates of F. oxysporum recovered from healthy, asymptomatic banana plants would carry no or very few SIX genes. A major finding of this study was the high frequency of SIX genes in endophytic isolates of Fusarium associated with asymptomatic banana hosts. Similarly, Jelsinki et al. had also reported the occurrence of SIX gene homologues in a high proportion of putatively endophytic isolates of F. oxysporum recovered from tomato producing fields [53]. These results are contradictory to Rocha et al. and Inami et al., which both reported a low or no incidence of SIX genes in putatively endophytic or saprophytic isolates of F. oxysporum [49,52]. The disparity between the results of these studies could be due to the land use and the environment from which the endophytes have been recovered. Both this study and Jelsinki et al. targeted endophytes in hosts being grown for agricultural purposes. In contrast, Rocha et al. and Inami et al. recovered putatively endophytic or saprophytic isolates of Fusarium from natural ecosystems or wild, uncultivated hosts. In intensive agricultural systems, effectors (such as the SIX proteins) could be important to the endophytic, as well as the pathogenic isolates of Fusarium as they may facilitate the growth and survival of the fungus as an asymptomatic biotroph. For endophytic Fusarium, the ability to better colonise and survive within their host may give the isolates a significant advantage of other fungi that are present in the same niche. Therefore, it is hypothesised that the high frequency of SIX genes in the endophytes of Fusarium may be the result of positive selection for endophytic isolates whose genomes include features, such as effectors that enable them to be better competitors in the ecological niche of a host plant, particularly in intensive agricultural systems.

There is increasing evidence that many mycorrhizal and endophytic species of fungi utilise effectors to successfully establish their mutualistic relationships with their hosts (reviewed by References [56,57]). The functions of three effectors in three mycorrhizal species have been well-studied with interesting results. The SP7 effector in the mutualist, Rhizophagus irregularis, and the MiSSP7 effector in Laccaria bicolour have both been shown to modulate plant hormone signalling pathways, thereby downregulating the host defence responses [58-62]. The increasing number of sequenced genomes representing mycorrhizal and endophytic species have shown that hundreds of effector candidates are predicted to be encoded by these species [63-65]. It is possible that similar to mycorrhizal species of fungi, the endophytic isolates of F. oxysporum also utilise effectors to suppress a host's defence responses to facilitate the establishment of an intimate endophytic relationship. However, the studies to date that have investigated the presence of SIX genes in environmental isolates of F. oxysporum have not established if the SIX genes or other effectors are expressed or functional in these non-pathogenic interactions.

An alternative explanation for the increased frequency of SIX genes identified in the endophytic isolates compared to other studies is due to the primers used in this study. The universal primers developed in this study to amplify all SIX gene homologues that were known at the time of this could account for the increased frequency of SIX gene detection in isolates of Fusarium. The other studies, such as Inami et al., Rocha et al. and Jelinski et al., utilised primers that were commonly designed to amplify SIX genes from specific formae speciales $[49,52,53]$. While the use of PCR worked well for our purposes, it is an approach that is biased towards identifying known orthologues of previously identified SIX genes. The most unbiased approach for effector discovery and analysis would be whole genome sequencing. Currently, the majority of genomes of $F$. oxysporum that have been sequenced represent pathogenic lineages, and only two genomes of putatively non-pathogenic isolates of $F$. oxysporum are publicly available. The two sequenced genomes of non-pathogenic $F$. 
oxysporum, Fo47 and MN14, both show a reduced accessory genome [38,39]. These isolates were also shown by van Dam and Rep to have reduced numbers of a transposable element class termed mimps, which are associated with the promoter region of the SIX genes and other predicted effector candidates of F. oxysporum [28,42]. Interestingly, the genomes of Foc also shared similar hallmarks similar to the non-pathogenic isolates, including a small accessory genome and reduced number of identified mimps [38,39,42].

The cluster analysis of this study was also important for demonstrating that the SIX gene profiles of the putatively endophytic isolates were not the same as the SIX gene profiles of pathogenic formae speciales of $F$. oxysporum that were assessed in this study. Following the identification of the SIX genes in putatively endophytic isolates of Fusarium, it was hypothesised that endophytes from healthy, asymptomatic bananas should not have the same SIX gene profile as the pathogenic lineages of Foc. A hierarchical cluster analysis supported this hypothesis, and based on their SIX gene profiles, the majority of the endophytic isolates clustered separately from the pathogenic lineages of F. oxysporum. Several isolates of F. oxysporum recovered from Mullumbimby shared the same SIX gene profile as the race 1 VCGs of Foc, and some of the isolates recovered from Redlands clustered with the SR4 VCGs of Foc. These isolates also had an identical EF1- $\alpha$ sequence to the respective pathogenic VCGs of Foc. In both of these instances, the plants from which these isolates were recovered displayed both external and internal symptoms of Fusarium wilt at the time of sampling. Based on the SIX gene profiles and sequencing of the EF1- $\alpha$ locus, the race of Foc that was causing disease at both sites was identified, thus, demonstrating the utility of the SIX gene presence/absence typing.

The diagnostic potential of the SIX genes in Foc has also been utilised by Carvalhais et al. in the design and development of a molecular assay capable of distinguishing between the various races and vegetative compatibility groups (VCGs) of Foc [66]. Typically, molecular diagnostics are developed to be able to rapidly identify the intended target organism and return a binary 'yes/no' answer. This approach to molecular diagnostics is favoured for pathogens, such as TR4, due to the ability to design an assay that is sensitive, specific and fast. However, these methods of developing diagnostics have limitations, such as requiring an extensive prior understanding of the target pathogen. As a result, this approach to molecular diagnostics is often not effective and identifying or characterising novel pathotypes or even novel formae speciales. The future of molecularbased diagnostics of the F. oxysporum species complex lies in the ability to predict an isolate's pathogenic potential from its genomic information. The diagnostic utility of the SIX genes and effectors more broadly has the potential to provide a novel means of pathogen identification and characterisation in the F. oxysporum species complex. Developing an improved understanding of effector presence/absence and evolution in the genetically diverse range of non-pathogenic and endophytic isolates of Fusarium will be critical to the future utility of an effector-based multi-locus sequencing typing of Fusarium.

In conclusion, this study has demonstrated that many of the Fusarium species isolated from healthy, asymptomatic banana tissue carry one or more SIX genes. Furthermore, the SIX gene profiles of isolates that are pathogenic to bananas have a complement of SIX genes that is distinct from their non-pathogenic counterparts. The results of this study could indicate that endophytic isolates of Fusarium, including F. oxysporum, could indicate that putative endophytes acquire and/or retain effectors to better colonise hosts and become more competitive in the ecological niche of a host banana plant. Although there may be a selective advantage for isolates that carry effectors, the endophytes may not be unable to cause disease in banana as they lack the full complement of molecular machinery required for virulence. Currently, the means by which putative endophytes acquire SIX genes is unknown and requires further investigation. While horizontal chromosome transfer has been reported in pathogenic lineages of Foc, it is not known whether SIX genes are also acquired by endophytes via HCT. This study is an important demonstration that endophytic Fusarium could be potential reservoirs of effector genes and could contribute to the evolution of novel pathotypes of F. oxysporum. For this reason, the endophytic and 
putatively non-pathogenic lineages of $F$. oxysporum continue to be of significant interest and warrant further research.

\section{Materials and Methods}

\subsection{Universal Primer Design for SIX1-SIX14}

The design of universal primers to amplify SIX1-SIX14 was performed by identifying highly conserved sites suitable for primer design parameters in multiple sequence alignments of each gene constructed from sequence data available on GenBank (www.ncbi. nlm.nih.gov/genbank (accessed on 28 February 2021)). For each SIX gene, corresponding sequence homologues in the National Centre for Biotechnology Information (NCBI) nucleotide database and in the genomes of Fusarium oxysporum available on the whole genome sequencing database using BLAST were retrieved (version 2.7.0, National Centre for Biotechnology Information, Bethesda, MD, USA; accessed 17 January 2017). The coding sequences of the SIX genes from Fol were used as the query sequences (Supplementary Table S1). Sequences that aligned to the query sequence with an E-value of $<0.05$ were aligned using the online sequence alignment tool, MAFFT (version 7.307, Research Institute for Microbial Diseases, Osaka, Japan; mafft.cbrc.jp/alignment/server) using the G-INS-1 method. The resulting sequence alignments were imported into Geneious (version 6.8.1, Biomatter Pty. Ltd., AKLD, New Zealand; [67]) and were manually inspected and adjusted if required. Primer pairs that amplified all sequence homologues of a SIX gene were designed to highly conserved regions of the genes using the primer3 plugin within Geneious (version 6.8.1, Biomatter Pty. Ltd., AKLFD, New Zealand) (Table 4). The following parameters were used by primer3 to design the primers; regions with at least $75 \%$ identity, annealing temperature range of $57-63^{\circ} \mathrm{C}$ with an optimal temperature of $60^{\circ} \mathrm{C}$, maximum of $5{ }^{\circ} \mathrm{C}$ difference between primer pairs, and the resulting primer pairs had no or low duplex potential. For SIX6, SIX9 and SIX13, where primer3 was unable to identify suitable sites, primer pairs were manually designed to highly conserved regions with a maximum of $5{ }^{\circ} \mathrm{C}$ difference between primer pairs, and the resulting primer pairs had no, or low, duplex potential as assessed by primer3. The annealing temperature and duplex potential for manually designed primers were determined using the primer3 feature within Geneious (version 6.8.1, Biomatter Pty. Ltd., AKLD, New Zealand).

Table 4. PCR primers used in this study, including the expected amplicon size and annealing temperature for the primers. Primers for the translation elongation factor 1- $\alpha(E F 1-\alpha)$ were as described by O'Donnell et al. [19]. Universal primers for the SIX genes were all designed as part of this study.

\begin{tabular}{|c|c|c|c|c|}
\hline Gene Target & Primers & Sequence $\left(5^{\prime}-3^{\prime}\right)$ & $\begin{array}{c}\text { Expected } \\
\text { Amplicon Size } \\
\text { (Base Pairs) }\end{array}$ & $\begin{array}{c}\text { Annealing } \\
\text { Temperature }\left({ }^{\circ} \mathrm{C}\right)\end{array}$ \\
\hline \multirow{2}{*}{$E F 1-\alpha$} & EF1-F & ATGGGTAAGGARGACAAGAC & \multirow{2}{*}{$\sim 650$} & \multirow{2}{*}{$55^{\circ} \mathrm{C}$} \\
\hline & EF2-R & GGARGTACCAGTSATCATGTT & & \\
\hline \multirow{2}{*}{ SIX1 } & SIX1f & TCT CCA TTA CTT TGT CTC ACG & \multirow{2}{*}{$694-733$} & \multirow{2}{*}{$58^{\circ} \mathrm{C}$} \\
\hline & SIX1r & CGA TTT AGG CGA TTC GGG G & & \\
\hline \multirow{2}{*}{ SIX2 } & SIX2f & GGT TCC CAT CGT TGA AGC & \multirow{2}{*}{$327-330$} & \multirow{2}{*}{$57^{\circ} \mathrm{C}$} \\
\hline & SIX2r & TTG GTT TAA ATC TGC GTG TC & & \\
\hline \multirow[b]{2}{*}{ SIX3 } & SIX3f & TTA CTA CGA GCT TCA GCA CC & \multirow[b]{2}{*}{223} & \multirow{2}{*}{$60^{\circ} \mathrm{C}$} \\
\hline & SIX3r & GCA TTA GGT GTT GCA ACA GG & & \\
\hline \multirow{2}{*}{ SIX4 } & SIX4f & CAG CTC AGA CAG TCA GCC & \multirow{2}{*}{$\sim 491$} & \multirow{2}{*}{$58^{\circ} \mathrm{C}$} \\
\hline & SIX4r & GGC CTT GAG TCG AAT GAG C & & \\
\hline \multirow{2}{*}{ SIX5 } & SIX5f & TCA TCA GTA CTG TGC TTG CC & \multirow[b]{2}{*}{$347-354$} & \multirow[b]{2}{*}{$59^{\circ} \mathrm{C}$} \\
\hline & SIX5r & CAT GTT GAG TCT GCT CCT CC & & \\
\hline \multirow{2}{*}{ SIX6 } & SIX6f & CTC TCG AGA CAC SCT TCC & \multirow{2}{*}{$396-399$} & \multirow{2}{*}{$58^{\circ} \mathrm{C}$} \\
\hline & SIX6r & GAT CCA CCA ATA CCT TCA T & & \\
\hline \multirow{2}{*}{ SIX7 } & SIX7f & GAG GTG ACA TTT GAC ATC ACC & \multirow{2}{*}{113} & \multirow{2}{*}{$60^{\circ} \mathrm{C}$} \\
\hline & SIX7r & TAG TAT GCG CGC CAT TGG & & \\
\hline
\end{tabular}


Table 4. Cont.

\begin{tabular}{|c|c|c|c|c|}
\hline Gene Target & Primers & Sequence $\left(5^{\prime}-3^{\prime}\right)$ & $\begin{array}{c}\text { Expected } \\
\text { Amplicon Size } \\
\text { (Base Pairs) }\end{array}$ & $\begin{array}{c}\text { Annealing } \\
\text { Temperature }\left({ }^{\circ} \mathrm{C}\right)\end{array}$ \\
\hline SIX8 & $\begin{array}{l}\text { SIX8f } \\
\text { SIX8r }\end{array}$ & $\begin{array}{c}\text { CCC TAG CCG TCT CTG TGG C } \\
\text { CGT TCG ACA AGG GCT CTC TCG }\end{array}$ & $163-165$ & $64^{\circ} \mathrm{C}$ \\
\hline SIX9 Group 1 & $\begin{array}{l}\text { SIX9f-G1 } \\
\text { SIX9r-G1 }\end{array}$ & $\begin{array}{l}\text { TTC AAG TCG GTT GCT ACG C } \\
\text { GCA TCC CAA AAT CCA AAG CG }\end{array}$ & 118 & $58^{\circ} \mathrm{C}$ \\
\hline SIX9 Group 2 & $\begin{array}{l}\text { SIX9f-G2 } \\
\text { SIX9r-G2 }\end{array}$ & $\begin{array}{c}\text { CCG TCT TCT CTA CCG CCG } \\
\text { AGT TGA CGC AAG CAA AGT CG }\end{array}$ & 288 & $58^{\circ} \mathrm{C}$ \\
\hline SIX10 & $\begin{array}{l}\text { SIX10f } \\
\text { SIX10r }\end{array}$ & $\begin{array}{l}\text { TCA CGT TTC GAG TTG GTC C } \\
\text { ACA CCA AAT CGA GTC GAT GC }\end{array}$ & 202 & $60{ }^{\circ} \mathrm{C}$ \\
\hline SIX11 & $\begin{array}{l}\text { SIX11f } \\
\text { SIX11r }\end{array}$ & $\begin{array}{l}\text { GTT GCT CCT CCT TTG CTG G } \\
\text { TAC CAC TCT GAC CAG TCA CC }\end{array}$ & 163 & $62{ }^{\circ} \mathrm{C}$ \\
\hline SIX12 & $\begin{array}{l}\text { SIX12f } \\
\text { SIX12r }\end{array}$ & $\begin{array}{l}\text { CAG AAT GCT TGT GTG TGT GG } \\
\text { ATC ACC AGA GCA TGA ACC CC }\end{array}$ & 171 & $61^{\circ} \mathrm{C}$ \\
\hline SIX13 & $\begin{array}{l}\text { SIX13f } \\
\text { SIX13r }\end{array}$ & $\begin{array}{l}\text { TCT GAT CAG CCT CCT AGC GT } \\
\text { CCA CTG TAA CTC GGC ATC GA }\end{array}$ & 840 & $60{ }^{\circ} \mathrm{C}$ \\
\hline SIX14 & $\begin{array}{l}\text { SIX14f } \\
\text { SIX14r }\end{array}$ & $\begin{array}{l}\text { TGT CTC AGC GTA TCC TCG GC } \\
\text { ATT CAG TGA CAA CGG GAC CG }\end{array}$ & 147-197 & $61^{\circ} \mathrm{C}$ \\
\hline
\end{tabular}

For SIX9, a single pair of primers could not be designed to amplify all sequence homologues of SIX9. Instead, the sequence homologues were grouped into either Group 1 or Group 2 (Figure S1). Generally speaking, homologues that had $<75 \%$ homology to the reference sequence from Fol-4287 (GenBank accession XM_018394292.1) were considered Group 1 and the primers SIX9f-G1 and SIX9r-G1 were designed to amplify the homologues in this group. Those homologues that had $>75 \%$ homology to reference sequence of SIX 9 from Fol-4287 were considered Group 2, and the primers SIX9f-G2 and SIX9r-G2 were designed to amplify the homologues in this group.

\subsection{Culturing and Nucleic Acid Extraction}

Monoconidial cultures of F. oxysporum were initiated from carnation leaf stocks onto $1 / 4$ potato dextrose agar (PDA) (Difco Laboratories, Becton Dickinson Diagnostics, East Rutherford, NJ, USA) and incubated in the dark at $24{ }^{\circ} \mathrm{C}$ for seven days. A mycelial plug from each culture was used to inoculate a $1 / 2$ potato dextrose broth culture (PDB; Difco Laboratories, Becton Dickinson Diagnostics, East Rutherford, NJ, USA). The broth cultures were shaken for seven days under $12 \mathrm{~h}$ light $/ 12 \mathrm{~h}$ dark cycles. Mycelia were harvested by filtering through Miracloth (Merck Merck \& Co., Galloping Hill Road Kenilworth, NJ, USA) and snap frozen in liquid nitrogen. The harvested mycelia were ground in liquid nitrogen, and nucleic acid was extracted using the CTAB method described by Leslie and Summerell [68]. The DNA concentration and purity were determined using a Nanodrop spectrophotometer (ThermoScientific, Waltham, MA, USA) and diluted to $~ 50 \mathrm{ng} / \mathrm{uL}$ with nuclease-free water.

4.3. Optimisation and Screening of F. oxysporum Formae Speciales with Universal Primers for the SIX Genes

The universal primers targeting the SIX genes were validated and optimised against a panel of isolates belonging to formae speciales of F. oxysporum whose SIX gene profiles could be established from data available from NCBI. To first establish the SIX gene profiles of the formae speciales listed in Table 5 , the genomes of the formae speciales that were available on the NCBI genome database were queried using sequence homologues of the SIX genes identified in Fol using BLAST (version 2.7.0, National Centre for Biotechnology Information, Bethesda, MA, USA) (Table S1). To optimise the thermocycling conditions, the optimal annealing temperature for each primer pair was identified using a gradient PCR. The optimal annealing temperature was defined as the temperature at which non-specific amplicons were eliminated, while retaining efficient amplification of the target loci. Amplification of 
the EF1- $\alpha$ region using the primers, EF1 and EF2, described by O'Donnell et al., confirmed that the DNA was of suitable quality for PCR assays [19]. All PCRs were conducted in 25 $\mu \mathrm{L}$ reactions consisting of $12.5 \mu \mathrm{L}$ Promega GoTaq Green Master Mix (2X; Promega Corporation, Fitchburg, WI, USA), $1 \mu \mathrm{L}$ forwards primer (10 $\mu \mathrm{M}$; Integrated DNA Technologies Inc.), $1 \mathrm{uL}$ reverse primer ( $10 \mu \mathrm{M}$; Integrated DNA Technologies Inc.), $1 \mathrm{uL}$ of template DNA $(\sim 50 \mathrm{ng} / \mathrm{uL})$ and $9.5 \mu \mathrm{L}$ of nuclease-free $\mathrm{H}_{2} \mathrm{O}$. PCR amplification reactions were conducted using a Bioline thermocycler thermocycler (Meridian Bioscience Incorporated, London, England). The thermocycling conditions were as follows: (i) An initial denaturation at $95^{\circ} \mathrm{C}$ for $2 \mathrm{~min}$ followed by (ii) 35 cycles of $95^{\circ} \mathrm{C}$ for $30 \mathrm{~s}$, then an annealing temperature as detailed in Table 4 for $30 \mathrm{~s}$, and an extension time as detailed in Table 4 at $72{ }^{\circ} \mathrm{C}$, and finally, (iii) a final extension time of $72{ }^{\circ} \mathrm{C}$ for $5 \mathrm{~min}$. Amplicons were size separated on a $1.5 \%$ agarose gel stained with ethidium bromide and visualised on a UV transilluminator. To confirm the specificity of the PCR amplifications, PCR amplicons were purified using the Promega Wizard PCR Purification Kit (Promega Corporation, Fitchburg, WI, USA) and sequenced at Macrogen (Macrogen Inc., Seoul, Korea) using the primers in Table 4. The resulting chromatograms were manually edited in Geneious version 6.8.1, Biomatter Pty. Ltd., AKLD, New Zealand) to remove low quality or ambiguous sequences. To confirm the sequence identity of the PCR amplicons, the sequences were used to query the nucleotide BLAST database. (version 2.7.0, National Centre for Biotechnology Information, Bethesda, MA, USA). The sequences were used in a multiple sequence alignment that also included the original SIX gene sequences used to develop the primers. The results of the universal SIX gene primer PCRs were cross-referenced to previous published SIX gene profiles for each isolate to identify any conflicting results.

Table 5. Isolates of F. oxysporum used to validate and optimise the universal secreted in xylem (SIX) gene primers. Abbreviated names of the formae speciales are indicated inside parentheses after the name of the forma specialis.

\begin{tabular}{|c|c|c|c|}
\hline Forma Specialis & Accession Code ${ }^{1}$ & $\mathrm{VCG}^{2}$ & Host \\
\hline \multirow{26}{*}{$\begin{array}{l}\text { conglutinans (Focg) } \\
\text { cubense (Foc) }\end{array}$} & BRIP5176 & NA & Brassica oleracea var. capitate \\
\hline & BRIP62933 & 0124 & Musa sp. (unidentified) \\
\hline & BRIP62895 & 0123 & Musa sp. AAB 'Latundan' \\
\hline & BRIP58698 & 01217 & Musa sp. (unidentified) \\
\hline & BRIP40340 & 01213 & Musa sp. AAA ‘Cavendish' \\
\hline & BRIP62962 & 0121 & Musa sp. AA 'Sucrier' \\
\hline & BRIP62892 & 0122 & Musa sp. AAA ‘Cavendish' \\
\hline & NRRL36118 & 01221 & Musa sp. ABB 'Pisang Awak' \\
\hline & BRIP44012 & 0120 & Musa sp. AAA ‘Cavendish' \\
\hline & BRIP63259 & 01218 & Musa sp. (unidentified) \\
\hline & BRIP62779 & 01216 & Musa sp. AAA 'Cavendish' \\
\hline & BRIP39259 & 01211 & Musa sp. AAB ‘Lady Finger’ \\
\hline & BRIP62911 & 0124 & Musa sp. (unidentified) \\
\hline & NRRL36113 & 01214 & Musa sp. ABB ‘Bluggoe' \\
\hline & NRRL25609 & 01214 & Musa sp. ABB 'Harare' \\
\hline & NRRL26029 & 01210 & Musa sp. AAB 'Silk' \\
\hline & BRIP62957 & 0125 & Musa sp. (unidentified) \\
\hline & BRIP59161 & 0126 & Musa sp. (unidentified) \\
\hline & BRIP22887 & 0128 & Musa sp. ABB ‘Bluggoe' \\
\hline & BRIP40255 & 0129 & Musa sp. AAB ‘Lady Finger’ \\
\hline & NRRL36112 & 01215 & Musa sp. AAA 'Cavendish' \\
\hline & BRIP59147 & 01217 & Musa sp. (unidentified) \\
\hline & BRIP58634 & 01219 & Musa sp. (unidentified) \\
\hline & BRIP58803 & 01220 & Musa sp. (unidentified) \\
\hline & BRIP59170 & 01222 & Musa sp. (unidentified) \\
\hline & BRIP62955 & 01212 & Musa sp. (unidentified) \\
\hline \multirow[t]{3}{*}{ fragariae (Fof) } & BRIP53860 & NA & Fragaria $\times$ ananassa \\
\hline & BRIP62107 & NA & Fragaria $\times$ ananassa \\
\hline & BRIP62106 & NA & Fragaria $\times$ ananassa \\
\hline
\end{tabular}


Table 5. Cont.

\begin{tabular}{|c|c|c|c|}
\hline Forma Specialis & Accession Code ${ }^{1}$ & $\mathrm{VCG}^{2}$ & Host \\
\hline \multirow[t]{3}{*}{ lycopersici (Fol) } & BRIP63541 & NA & Solanum lycopersicum \\
\hline & $4287^{3}$ (NRRL34936) & 0030 & Solanum lycopersicum \\
\hline & MN25 ${ }^{3}$ (NRRL54003) & 0033 & Solanum lycopersicum \\
\hline \multirow{5}{*}{$\begin{array}{l}\text { medicaginis (Fomg) } \\
\text { niveum (Fon) }\end{array}$} & BRIP5189 & NA & Medicago sativa \\
\hline & NT-DPI36955 & NA & Citrullus sp. \\
\hline & BRIP5178 & NA & Citrullus lanatus \\
\hline & BRIP5177 & NA & Citrullus lanatus \\
\hline & BRIP5181 & NA & Citrullus lanatus \\
\hline \multirow[t]{2}{*}{ passiflorae (Fopf) } & BRIP28044 & NA & Passiflora edulis \\
\hline & BRIP5192 & NA & Passiflora edulis \\
\hline \multirow[t]{10}{*}{ vasinfectum (Fov) } & NRRL25433 & 0114 & Gossypium hirsutum \\
\hline & BRIP25372 & 01111 & Gossypium hirsutum \\
\hline & BRIP43365 & NA & Gossypium hirsutum \\
\hline & BRIP63607 & NA & Gossypium hirsutum \\
\hline & BRIP43351 & NA & Gossypium hirsutum \\
\hline & BRIP25374 & 01112 & Gossypium hirsutum \\
\hline & BRIP43344 & NA & Gossypium hirsutum \\
\hline & BRIP43336 & NA & Gossypium hirsutum \\
\hline & BRIP43339 & NA & Gossypium hirsutum \\
\hline & BRIP43356 & NA & Gossypium hirsutum \\
\hline \multirow{2}{*}{ zingerberi (Foz) } & BRIP39299 & NA & Zingiber officinale \\
\hline & BRIP44986 & NA & Zingiber officinale \\
\hline
\end{tabular}

${ }^{1}$ BRIP-Brisbane Plant Pathology Herbarium, NT-DPI-Northern Territory Department of Primary Industries, NRRL-Agricultural Research Service Culture Collection, United States Department of Agriculture. ${ }^{2}$ VCG-Vegetative Compatibility Group. NA was assigned to isolates where VCGs were unknown. ${ }^{3}$ strain number commonly used for these isolates.

\subsection{Isolation of Fusarium Species Associated with Asymptomatic Bananas}

To investigate the presence of SIX genes in Fusarium spp. associated with asymptomatic banana, sampling of banana plants with no external symptoms of infection by Foc was conducted at two locations. The first location was at the Redlands Research Station (Redlands, QLD, Australia). This site maintains several stands of the wild banana species, Musa acuminata subsp. malaccensis. Five plants that appeared healthy and with no external symptoms of wilting were chosen for sampling. At this site, an additional three plants showed internal and external symptoms of Fusarium wilt. Tissue was still collected from symptomatic plants for further analysis to determine if Foc could be identified. For each plant, several samples of pseudostem and root tissue were harvested for isolations. The second location was a commercial banana plantation that grew the banana cultivar, 'Lady Finger'. Eighteen plants that appeared healthy and with no external symptoms of wilting were chosen for sampling. An additional two plants exhibited external and internal symptoms of Fusarium wilt disease. Tissue was isolated from this plant to determine if Foc could be identified. From these plants, tissue from the roots, lower pseudostem $(\sim 1$ $\mathrm{m}$ from ground level), upper pseudostem ( $\sim 3 \mathrm{~m}$ from ground level) and the peduncle of the plants was collected. Details of cultures isolated in this study are summarised in Supplementary Table S2.

The primary isolation of Fusarium spp. from the banana tissue was made by trimming excess tissue until the sections were $\sim 3 \mathrm{~cm} \times \sim 3 \mathrm{~cm}$. Tissue segments were surface sterilised by immersing in a 1:10 hypochlorite solution for $60 \mathrm{~s}$ before rinsing in sterile distilled water and dried on sterile blotting paper. The sterilised tissue segments were then further aseptically dissected into pieces of $\sim 1 \mathrm{~cm}$ lengths, and plated onto half-strength PDA (Difco Laboratories, Becton Dickinson Diagnostics, East Rutherford, NJ, USA) amended with $100 \mathrm{mg} / \mathrm{mL}$ of streptomycin (Sigma Aldrich, MO, USA). The primary cultures were incubated at $24{ }^{\circ} \mathrm{C}$ in dark conditions and checked daily for $\sim 7$ days for Fusarium-like growth according to features described in Leslie and Summerell [68]. Cultures that had morphological features typical of Fusarium species as described by Leslie and Summerell 
were subcultured onto water agar for single sporing [68]. The pure cultures were incubated at $24{ }^{\circ} \mathrm{C}$ for 5 days before mycelia were harvested for DNA extractions and PCR screens.

\subsection{Phylogenetic Analysis}

Amplicons from the EF1- $\alpha$ PCR were purified using the Promega Wizard PCR Product and Gel Clean Up Kit (Promega Corporation, WI, USA) and sequenced at Macrogen (Macrogen Inc., Seoul, Korea). To identify the species of the Fusarium endophytes the resulting $E F 1-\alpha$ sequences were manually edited to remove low quality sequences in Geneious (version 6.8.1, Biomatter Pty. Ltd., AKLD, New Zealand)) and used as query sequences to perform BLAST searches of the NCBI nucleotide database (version 2.7.0, National Centre for Biotechnology Information, Bethesda, MA, USA), EF1- $\alpha$ dataset in FusariumID (http:/ / isolate.fusariumdb.org/ (accessed on 28 February 2021)) and the Fusarium Multilocus Sequence Typing database (http:/ / www.westerdijkinstitute.nl/fusarium/ (accessed on 28 February 2021)). The EF1- $\alpha$ sequences of Fusarium species were aligned with MAFFT (version 7.307, Research Institute for Microbial Diseases, Osaka, Japan; https://mafft.cbrc.jp/alignment/server/ (accessed on 28 February 2021)) using the G-INS1 parameters. The resulting sequence alignment was manually inspected ambiguously aligned regions were trimmed. The EF1- $\alpha$ alignment was analysed using Bayesian inference using MrBayes (version3.2.7, Department of Biodiversity Informatics, Stockholm, Sweden [69]) using the GTR-G-I model of substitution. Two independent analyses were conducted for four Markov chain Monte Carlo (MCMC) chains for 2000000 generations. The analysis was sampled every 1000 generations with a burn-in of $25 \%$. A maximum likelihood analysis (ML) with RAxML (version8.1, version 8.1, Scientific Computing Group, Heidelberg Institute for Theoretical Studies, Heidelberg, Germany; [70]) was also undertaken. Trees were visualised, and tree images were generated using iTOL (version 3.6, European Molecular Biology Laboratory, Heidelberg, Germany; [71]).

\subsection{Screening of Fusarium Cultures for SIX Genes}

DNA was extracted from the cultures of Fusarium isolated from banana tissue using the process previously described. To ensure that (i) the DNA was of sufficient quality for PCR, and (ii) the cultures were Fusarium species, amplification of a region in the EF1- $\alpha$ was conducted as previously described. Isolates that had an EF1- $\alpha$ amplicon of the expected size were further assessed for SIX genes using the optimised universal primers. Amplification of SIX1-SIX14 was performed using the optimised conditions described above and in Table 4. Amplicons were size separated and visualised as previously described. The EF1- $\alpha$ and SIX gene amplicons of the expected sized were purified using the Wizard PCR and Gel Clean Up kit (Promega Corporation, WI, USA) and sequenced by Macrogen (Macrogen Inc., Seoul, Korea) using the primers used for amplification of the target gene. The resulting EF1- $\alpha$ and SIX gene sequences were deposited to GenBank (accessions MW076542-MW076821).

\subsection{Sequencing Analysis of the SIX Genes}

The chromatograms of the EF1- $\alpha$ and SIX gene amplicons were visualised in Geneious (version 6.8.1, Biomatter Pty. Ltd., AKLD, New Zealand) and manually edited to remove low quality or ambiguous sequencing results. To confirm the sequence identity of the SIX gene amplicons from the panel of formae speciales and from the primary cultures, the sequences were used to query the nucleotide BLAST database (version 2.7.0, National Centre for Biotechnology Information, Bethesda, MA, USA). The sequences were compared reference SIX gene sequences from other formae speciales by multiple sequence alignments and gene trees inferred using Bayesian inference with MrBayes (version 3.2.7, Department of Biodiversity Informatics, Stockholm, Sweden; [69]). The GTR-G-I model of substitution was implemented with two independent analyses for four Markov chain Monte Carlo (MCMC) chains. The number of generations was increased by 50,000 until the standard deviation of the split frequencies fell below 0.01 . The analysis was sampled every 1000 generations with a burn-in of $25 \%$. Trees were visualised, and tree images generated using 
iTOL (version 3.6, European Molecular Biology Laboratory, Heidelberg, Germany; [71]) (Figure S1).

\title{
4.8. Cluster Analysis of SIX Gene Profile
}

Hierarchical clustering of the SIX gene profiles was performed by creating a binary matrix where gene presence was indicated by a " 1 " and gene absence was indicated by a " 0 ". The gene presence/absence data matrix was used to calculate a Jaccard distance matrix in R with the 'vegan' package (version. 2.5-2; [72]), which was then used as input for hierarchical clustering with the average linkage in the 'cluster' package in $\mathrm{R}$ (version. 2.0.7-1; [73]).

Supplementary Materials: Supplementary materials can be found at https:/ /www.mdpi.com/1422 $-0067 / 22 / 5 / 2508 / s 1$. Supplementary Table S1 Genbank accessions of the SIX gene homologues from Fusarium oxysporum f.sp. lycopersici ( $F o l$ ) used as query sequences to search the BLAST nucleotide database for SIX gene orthologues. Supplementary Table S2 Details of Fusarium species isolated during this study. Figure S1 Neighbour-joining tree of SIX9 homologues identified with BLAST from the nucleotide database and genomes of Fusarium oxysporum available on the whole genome data base (NCBI). Figure S2 Gene trees of SIX genes identified and sequenced in this study.

Author Contributions: Conceptualization, E.C., I.Z.-R. and E.A.B.A.; methodology, E.C.; investigation, E.C. and I.Z.-R.; resources, E.A.B.A.; writing—original draft preparation, E.C.; writing-review and editing, E.C., I.Z.-R. and E.A.B.A.; funding acquisition, E.A.B.A. All authors have read and agreed to the published version of the manuscript.

Funding: This research was funded by Horticultural Innovation Australia, BA16005 Banana Diagnostics and BA10020 Banana Plant Protection Program.

Institutional Review Board Statement: Not applicable.

Informed Consent Statement: Not applicable.

Data Availability Statement: The data presented in this study are openly available in GenBank at MW076542-MW076821.

Acknowledgments: The authors would like to acknowledge the assistance of Matt Weinert and Peter Molenaar for coordinating the field tips for the collection of Fusarium isolates. The authors would also like to thank Rebecca Lyons for her assistance reviewing this manuscript.

Conflicts of Interest: The authors declare no conflict of interest.

\author{
Abbreviations \\ bp base pair \\ BRIP Brisbane Plant Pathology Herbarium \\ DOAJ Directory of open access journals \\ $E F 1-\alpha \quad$ translation elongation factor $1-\alpha$ \\ f.sp. forma specialis \\ ff.spp. formae speciales \\ FFSC Fusarium fujikuroi species complex \\ FIESC Fusarium incarnatum-equiseti species complex \\ Foc Fusarium oxysporum f.sp. cubense \\ Focg Fusarium oxysporum f.sp. conglutinans \\ Fof Fusarium oxsporum f.sp. fragariae \\ Fol Fusarium oxysporum f.sp. lycopoersici \\ Fomg Fusarium oxysporum f.sp. medicaginis \\ Fon Fusarium oxysporum f.sp. niveum \\ Fopf Fusarium oxysporum f.sp. passiflora \\ FOSC Fusarium oxysporum species complex \\ Fov Fusarium oxysporum f.sp. vasinfectum \\ Foz Fusarium oxysporum f.sp. zingerberi
}




$\begin{array}{ll}\text { FSSC } & \text { Fusarium solani species complex } \\ \text { kb } & \text { kilobase } \\ \text { MCMC } & \text { Markov chain Monte Carlo } \\ \text { MDPI } & \text { Multidisciplinary Digital Publishing Institute } \\ \text { ML } & \text { Maximum likelihood } \\ \text { N/A } & \text { Not applicable } \\ \text { NCBI } & \text { National Centre Biotechnology Information } \\ \text { NRRL } & \text { Agricultural Research Service Culture Collection } \\ \text { NSW } & \text { New South Wales } \\ \text { PCR } & \text { polymerase chain reaction } \\ \text { PDA } & \text { Potato dextrose agar } \\ \text { QLD } & \text { Queensland } \\ \text { R4 } & \text { Race } 4 \\ \text { SIX } & \text { secreted in xylem } \\ \text { SR4 } & \text { Subtropical race 4 } \\ \text { TR4 } & \text { Tropical race 4 } \\ \text { VCG/s } & \text { Vegetative compatibility group/s }\end{array}$

\section{References}

1. Snyder, W.C.; Hansen, H.N. The Species Concept in Fusarium. Am. J. Bot. 1940, 27, 64-67. [CrossRef]

2. Gordon, T.R.; Martyn, R.D. The evolutionary biology of Fusarium oxysporum. Annu. Rev. Phytopathol. 1997, 35, 111-128. [CrossRef]

3. Kistler, H.C.; Alabouvette, C.; Baayen, R.P.; Bentley, S.; Brayford, D.; Coddington, A.; Correll, J.; Daboussi, M.A.; Elias, K.; Fernandez, D.; et al. Systematic numbering of vegetative compatibility groups in the plant pathogenic fungus Fusarium oxysporum. Phytopathology 1998, 88, 30-32. [CrossRef] [PubMed]

4. $\quad$ Baayen, R.P.; O’Donnell, K.; Bonants, P.J.; Cigelnik, E.; Kroon, L.P.; Roebroeck, E.J.; Waalwijk, C. Gene genealogies and AFLP analyses in the Fusarium oxysporum complex identify monophyletic and nonmonophyletic formae speciales causing wilt and rot disease. Phytopathology 2000, 90, 891-900. [CrossRef] [PubMed]

5. O’Donnell, K.; Gueidan, C.; Sink, S.; Johnston, P.R.; Crous, P.W.; Glenn, A.; Riley, R.; Zitomer, N.; Colyer, P.; Waalwijk, C.; et al. A two-locus DNA sequence database for typing plant and human pathogens within the Fusarium oxysporum species complex. Fungal Genet. Biol. 2009, 46, 936-948. [CrossRef]

6. Ploetz, R.C.; Correll, J.C. Vegetative Compatibility Among Races of Fusarium oxysporum f. sp. cubense. Plant Dis. 1988, 72, 325-328. [CrossRef]

7. Katan, T.; Di Primo, P. Current status of vegetative compatibility groups in Fusarium oxysporum. Phytoparasitica 1999, 27, 51-64. [CrossRef]

8. Stover, R.H. Fusarial wilt (Panama Disease) of Bananas and other Musa Species; Commonwealth Mycological Institute: Kew, UK, 1962.

9. Ploetz, R.C. Panama disease: Return of the first banana menace. Int. J. Pest Manag. 1994, 40, 326-336. [CrossRef]

10. Maryani, N.; Lombard, L.; Poerba, Y.S.; Subandiyah, S.; Crous, P.W.; Kema, G.H.J. Phylogeny and genetic diversity of the banana Fusarium wilt pathogen Fusarium oxysporum f. sp. cubense in the Indonesian centre of origin. Stud. Mycol. 2019, 92, 155-194. [CrossRef] [PubMed]

11. Lombard, L.; Sandoval-Denis, M.; Lamprecht, S.C.; Crous, P.W. Epitypification of Fusarium oxysporum-Clearing the taxonomic chaos. Persoonia 2019, 43, 1-47. [CrossRef]

12. Stover, R.H. Fusarium wilt of banana: Some history and current status of the disease. 1990. In Fusarium Wilt of Banana; Ploetz, R.C., Ed.; APS Press: St. Paul, MN, USA, 1990; pp. 1-7.

13. Moore, N.Y.; Pegg, K.G.; Allen, R.N.; Irwin, J.A.G. Vegetative compatibility and distribution of Fusarium oxysporum f.sp. cubense in Australia. Aust. J. Exp. Agric. 1993, 33, 797-802. [CrossRef]

14. García-Bastidas, F.A.; Ordóñez, N.; Konkol, J.; Al-Qasim, M.; Naser, Z.; Abdelwali, M.; Salem, N.; Waalwijk, C.; Ploetz, R.C.; Kema, G.H.J. First report of Fusarium oxysporum f. sp. cubense tropical race 4 associated with Panama disease of banana outside southeast Asia. Plant Dis. 2014, 98, 694.

15. Ploetz, R.; Freeman, S.; Konkol, J.; Al-Abed, A.; Naser, Z.; Shalan, K.; Bakakat, R.; Israeli, Y. Tropical race 4 of Panama disease in the Middle East. Phytoparasitica 2015, 43, 283-293. [CrossRef]

16. O’Neill, W.T.; Henderson, J.; Pattemore, J.A.; O'Dwyer, C.; Perry, S.; Beasley, D.R.; Tan, Y.P.; Smyth, A.L.; Goosem, C.H.; Thomson, K.M.; et al. Detection of Fusarium oxysporum f. sp. cubense tropical race 4 strain in northern Queensland. Australas. Plant Dis. Notes 2016, 11, 33. [CrossRef]

17. Ordoñez, N.; García-Bastidas, F.; Laghari, H.B.; Akkary, M.Y.; Harfouche, E.N.; al Awar, B.N.; Kema, G.H.J. First Report of Fusarium oxysporum f. sp. cubense Tropical Race 4 Causing Panama disease in Cavendish bananas in Pakistan and Lebanon. Plant Dis. 2016, 100, 209. 
18. Zheng, S.-J.; García-Bastidas, F.A.; Li, X.; Zeng, L.; Bai, T.; Xu, S.; Yin, K.; Li, H.; Fu, G.; Yu, Y.; et al. New geographical insights of the latest expansion of Fusarium oxysporum f.sp. cubense Tropical Race 4 into the greater Mekong subregion. Front. Plant Sci. 2018, $9,457$.

19. O'Donnell, K.; Kistler, H.C.; Cigelnik, E.; Ploetz, R.C. Multiple evolutionary origins of the fungus causing Panama disease of banana: Concordant evidence from nuclear and mitochondrial gene genealogies. PNAS 1998, 95, 2044-2049. [CrossRef]

20. Fourie, G.; Steenkamp, E.T.; Gordon, T.R.; Viljoen, A. Evolutionary relationships among the Fusarium oxysporum f. sp. cubense vegetative compatibility groups. Appl. Environ. Microbiol. 2009, 75, 4770-4781. [CrossRef]

21. Ordonez, N.; Seidl, M.F.; Waalwijk, C.; Drenth, A.; Kilian, A.; Thomma, B.P.H.J.; Ploetz, R.C.; Kema, G.H.J. Worse comes to worst: Bananas and Panama Disease-When plant and pathogen clones meet. PLoS Pathog. 2015, 11, 1-7. [CrossRef] [PubMed]

22. Czislowski, E.; Fraser-Smith, S.; Zander, M.; O’Neill, W.T.; Meldrum, R.A.; Tran-Nguyen, L.T.T.; Batley, J.; Aitken, E.A.B. Investigation of the diversity of effector genes in the banana pathogen, Fusarium oxysporum $\mathrm{f}$. sp. cubense, reveals evidence of horizontal gene transfer. Mol. Plant Pathol. 2018, 19, 1155-1171. [CrossRef] [PubMed]

23. Jones, J.D.G.; Dangl, J.L. The plant immune system. Nature 2006, 444, 323-329. [CrossRef]

24. Rep, M.; van der Does, H.C.; Meijer, M.; van Wijk, R.; Houterman, P.M.; Dekker, H.L.; De Koster, C.G.; Cornelissen, B.J.C. A small, cysteine-rich protein secreted by Fusarium oxysporum during colonization of xylem vessels is required for I-3-mediated resistance in tomato. Mol. Microbiol. 2004, 53, 1373-1383. [CrossRef]

25. Houterman, P.M.; Speijer, D.; Dekker, H.L.; de Koster, C.G.; Cornelissen, B.J.C.; Rep, M. The mixed xylem sap proteome of Fusarium oxysporum-infected tomato plants. Mol. Plant Pathol. 2007, 8, 215-221. [CrossRef]

26. Lievens, B.; Houterman, P.M.; Rep, M. Effector gene screening allows unambiguous identification of Fusarium oxysporum f. sp. lycopersici races and discrimination from other formae speciales. FEMS Microbiol. Lett. 2009, 300, 201-215. [PubMed]

27. Takken, F.; Rep, M. The arms race between tomato and Fusarium oxysporum. Mol. Plant Pathol. 2010, 11, 309-314. [CrossRef] [PubMed]

28. Schmidt, S.M.; Houterman, P.M.; Schreiver, I.; Ma, L.; Amyotte, S.; Chellappan, B.; Boeren, S.; Takken, F.L.W.; Rep, M. MITEs in the promoters of effector genes allow prediction of novel virulence genes in Fusarium oxysporum. BMC Genomics 2013, 14, 119. [CrossRef]

29. Houterman, P.M.; Ma, L.; van Ooijen, G.; de Vroomen, M.J.; Cornelissen, B.J.C.; Takken, F.L.W.; Rep, M. The effector protein Avr2 of the xylem-colonizing fungus Fusarium oxysporum activates the tomato resistance protein I-2 intracellularly. Plant J. 2009, 58, 970-978. [CrossRef] [PubMed]

30. Thatcher, L.F.; Gardiner, D.M.; Kazan, K.; Manners, J.M. A Highly Conserved Effector in Fusarium oxysporum is required for full virulence on Arabidopsis. Mol. Plant Microbe Interact. 2012, 25, 180-190. [CrossRef] [PubMed]

31. Gawehns, F.; Houterman, P.M.; Ichou, F.A.; Michielse, C.B.; Hijdra, M.; Cornelissen, B.J.C.; Rep, M.; Takken, F.L.W. The Fusarium oxysporum effector Six6 contributes to virulence and suppresses I-2-mediated cell death. Mol. Plant Microbe Interact. 2014, 27, 336-348. [CrossRef]

32. Ma, L.; Houterman, P.M.; Gawehns, F.; Cao, L.; Sillo, F.; Richter, H.; Clavijo-Ortiz, M.J.; Schmidt, S.M.; Boeren, S.; Vervoort, J.; et al. The AVR2-SIX5 gene pair is required to activate I-mediated immunity in tomato. New Phytol. 2015, 5, 507-518. [CrossRef]

33. van Dam, P.; Fokkens, L.; Ayukawa, Y.; Van Der Gragt, M.; Ter Horst, A.; Brankovics, B.; Houterman, D.M.; Arie, T.; Rep, M. A mobile pathogenicity chromosome in Fusarium oxysporum for infection of multiple cucurbit species. Sci. Rep. 2017, 7, 1-15. [CrossRef]

34. Ma, L.J.; van der Does, H.C.; Borkovich, K.A.; Coleman, J.J.; Daboussi, M.J.; Di Pietro, A.; Dufresne, M.; Freitag, M.; Grabherr, M.; Henrissat, B.; et al. Comparative genomics reveals mobile pathogenicity chromosomes in Fusarium. Nature 2010, 464, 367-373. [CrossRef] [PubMed]

35. Fraser-Smith, S.; Czislowski, E.; Meldrum, R.A.; Zander, M.; O’Neill, W.; Balali, G.R.R.; Aitken, E.A.B. Sequence variation in the putative effector gene SIX8 facilitates molecular differentiation of Fusarium oxysporum f. sp. cubense. Plant Pathol. 2014, 63, 1044-1052. [CrossRef]

36. Laurence, M.H.; Summerell, B.A.; Liew, E.C.Y. Fusarium oxysporum f. sp. canariensis: Evidence for horizontal gene transfer of putative pathogenicity genes. Plant Pathol. 2015, 64, 1068-1075.

37. Taylor, A.; Vagany, V.; Jackson, A.; Harrison, R.; Rainoni, A.; Clarkson, J.P. Identification of pathogenicity-related genes in Fusarium oxysporum f. sp. cepae. Mol. Plant Pathol. 2016, 17, 1032-1047. [CrossRef] [PubMed]

38. Williams, A.H.; Sharma, M.; Thatcher, L.F.; Azam, S.; Hane, J.K.; Sperschneider, J.; Kidd, B.N.; Anderson, J.P.; Gosh, R.; Garg, G.; et al. Comparative genomics and prediction of conditionally dispensable sequences in legume-infecting Fusarium oxysporum formae speciales facilitates identification of candidate effectors. BMC Genom. 2016, 17, 191. [CrossRef]

39. van Dam, P.; Fokkens, L.; Schmidt, S.M.; Linmans, J.H.J.; Corby Kistler, H.; Ma, L.J.; Rep, M. Effector profiles distinguish formae speciales of Fusarium oxysporum. Environ. Microbiol. 2016, 18, 4087-4102. [CrossRef]

40. van der Does, H.C.; Lievens, B.; Claes, L.; Houterman, P.M.; Cornelissen, B.J.C.; Rep, M. The presence of a virulence locus discriminates Fusarium oxysporum isolates causing tomato wilt from other isolates. Environ. Microbiol. 2008, 10, $1475-1485$. [CrossRef]

41. van der Does, H.C.; Rep, M. Virulence genes and the evolution of host specificity in plant-pathogenic fungi. Mol. Plant Microbe Interact. 2007, 20, 1175-1182. [CrossRef] 
42. van Dam, P.; Rep, M. The distribution of miniature impala elements and SIX genes in the Fusarium genus is suggestive of horizontal gene transfer. J. Mol. Evol. 2017, 85, 14-25. [CrossRef]

43. van de Wouw, A.P.; Cozijnsen, A.J.; Hane, J.K.; Brunner, P.C.; McDonald, B.A.; Oliver, R.P.; Howlett, B.J. Evolution of linked avirulence effectors in Leptosphaeria maculans is affected by genomic environment and exposure to resistance genes in host plants. PLoS Pathog. 2010, 6, e1001180. [CrossRef] [PubMed]

44. Kleemann, J.; Rincon-Rivera, L.J.; Takahara, H.; Neumann, U.; van Themaat, E.V.L.; van der Does, H.C.; Hacquard, S.; Stuber, K.; Will, I.; Schmalenbach, W.; et al. Sequential delivery of host-induced virulence effectors by appressoria and intracellular hyphae of the phytopathogen Colletotrichum higginsianum. PLoS Pathog. 2012, 8, e1002643. [CrossRef]

45. Gan, P.; Ikeda, K.; Irieda, H.; Narusaka, M.; O’Connell, R.J.; Narusaka, Y.; Takano, Y.; Kubo, Y.; Shirasu, K. Comparative genomic and transcriptomic analyses reveal the hemibiotrophic stage shift of Colletotrichum fungi. New Phytol. 2013, 197, 1236-1249. [CrossRef]

46. Guo, L.; Han, L.; Yang, L.; Zeng, H.; Fan, D.; Zhu, Y.; Feng, Y.; Wang, G.; Peng, C.; Jiang, X.; et al. Genome and transcriptome analysis of the fungal pathogen Fusarium oxysporum f. sp. cubense causing banana vascular wilt disease. PLoS ONE 2014, 9, e95543

47. Photita, W.; Lumyong, S.; Lumyong, P.; Hyde, K.D. Endophytic fungi of wild banana (Musa acuminata) at Doi Suthep Pui National Park, Thailand. Mycol. Res. 2001, 105, 1508-1513. [CrossRef]

48. Athman, S.Y.; Dubois, T.; Coyne, D.; Gold, C.S.; Labuschagne, N.; Viljoen, A. Effect of endophytic Fusarium oxysporum on host preference of Radopholus similis to tissue culture banana plants. J. Nematology 2006, 38, 455-460.

49. Inami, K.; Kashiwa, T.; Kawabe, M.; Onokubo-Okabe, A.; Ishikawa, N.; Pérez, E.R.; Hozumi, T.; Caballero, L.A.; de Baldarrago, F.C.; Roco, M.J.; et al. The tomato wilt fungus Fusarium oxysporum f. sp. lycopersici shares common ancestors with nonpathogenic F. oxysporum isolated from wild tomatoes in the Peruvian Andes. Microbes Environ. 2014, 29, 200-210. [PubMed]

50. Demers, J.E.; Gugino, B.K.; Jiménez-Gasco, M. Highly diverse endophytic and soil Fusarium oxysporum populations associated with field-grown tomato plants. Appl. Environ. Microbiol. 2015, 81, 81-90. [CrossRef]

51. Zakaria, L.; Jamil, M.I.M.; Anuar, I.S.M. Molecular characterisation of endophytic fungi from roots of wild banana (Musa acuminata). Trop. Life Sci. Res. 2016, 27, 153-162. [PubMed]

52. Rocha, L.O.; Laurence, M.H.; Ludowici, V.A.; Puno, V.I.; Lim, C.C.; Tesoriero, L.A.; Summerell, B.A.; Liew, E.C.Y. Putative effector genes detected in Fusarium oxysporum from natural ecosystems of Australia. Plant Pathol. 2016, 65, 914-929. [CrossRef]

53. Jelinski, N.A.; Broz, K.; Jonkers, W.; Ma, L.J.; Kistler, H.C. Effector gene suites in some soil isolates of Fusarium oxysporum are not sufficient predictors of vascular wilt in tomato. Phytopathology 2017, 107, 842-851. [CrossRef]

54. Wang, B.; Brubaker, C.L.; Tate, W.; Woods, M.J.; Matheson, B.A.; Burdon, J.J. Genetic variation and population structure of Fusarium oxysporum f.sp. vasinfectum in Australia. Plant Path. 2006, 55, 746-755. [CrossRef]

55. Chakrabarti, A.; Rep, M.; Wang, B.; Ashton, A.; Dodds, P.; Ellis, J. Variation in potential effector genes distinguishing Australian and non-Australian isolates of the cotton wilt pathogen Fusarium oxysporum f.sp. vasinfectum. Plant Path. 2011, 60, 232-243. [CrossRef]

56. Rafiqi, M.; Ellis, J.G.; Ludowici, V.A.; Hardham, A.R.; Dodds, P.N. Challenges and progress towards understanding the role of effectors in plant-fungal interactions. Curr. Opin. Plant Biol. 2012, 15, 477-482. [CrossRef] [PubMed]

57. Plett, J.M.; Martin, F. Reconsidering mutualistic plant-fungal interactions through the lens of effector biology. Curr. Opin. Plant Biol. 2015, 26, 45-50. [CrossRef] [PubMed]

58. Camehl, I.; Sherameti, I.; Venus, Y.; Bethke, G.; Varma, A.; Lee, J.; Oelmüller, R. Ethylene signalling and ethylene-targeted transcription factors are required to balance beneficial and nonbeneficial traits in the symbiosis between the endophytic fungus Piriformospora indica and Arabidopsis thaliana. New Phytol. 2010, 185, 1062-1073. [CrossRef]

59. Kloppholz, S.; Kuhn, H.; Requena, N. A secreted fungal effector of Glomus intraradices promotes symbiotic biotrophy. Curr. Biol. 2011, 21, 1204-1209. [CrossRef] [PubMed]

60. Plett, J.M.; Kemppainen, M.; Kale, S.D.; Kohler, A.; Rie Legué, V.; Brun, A.; Tyler, B.M.; Pardo, A.G.; Martin, F. A secreted effector protein of Laccaria bicolor is required for symbiosis development. Curr. Biol. 2011, 21, 1197-1203. [CrossRef]

61. Plett, J.M.; Daguerre, Y.; Wittulsky, S.; Vayssières, A.; Deveau, A.; Melton, S.J.; Kohler, A.; Morrell-Falvey, J.L.; Brun, A.; VeneaultFourrey, C.; et al. Effector MiSSP7 of the mutualistic fungus Laccaria bicolor stabilizes the Populus JAZ6 protein and represses jasmonic acid (JA) responsive genes. PNAS 2014, 111, 8299-8304. [CrossRef] [PubMed]

62. Plett, J.M.; Khachane, A.; Ouassou, M.; Sundberg, B.; Kohler, A.; Martin, F. Ethylene and jasmonic acid act as negative modulators during mutualistic symbiosis between Laccaria bicolor and Populus roots. New Phytol. 2014, 202, 270-286. [CrossRef]

63. Martin, F.; Aerts, A.; Ahrén, D.; Brun, A.; Danchin, E.G.J.; Duchaussoy, F.; Gibon, J.; Kohler, A.; Lindquist, E.; Pereda, V.; et al. The genome of Laccaria bicolor provides insights into mycorrhizal symbiosis. Nature 2008, 452, 88-92. [CrossRef]

64. Zuccaro, A.; Lahrmann, U.; Gü Ldener, U.; Langen, G.; Pfiffi, S.; Biedenkopf, D.; Wong, P.; Samans, B.; Grimm, C.; Basiewicz, M.; et al. Endophytic life strategies decoded by genome and transcriptome analyses of the mutualistic root symbiont Piriformospora indica. PLOS Pathog. 2011, 7, e1002290. [CrossRef] [PubMed]

65. Kohler, A.; Kuo, A.; Nagy, L.G.; Morin, E.; Barry, K.W.; Buscot, F.; Canback, B.; Choi, C.; Cichocki, N.; Clum, A.; et al. Convergent losses of decay mechanisms and rapid turnover of symbiosis genes in mycorrhizal mutualists. Nat. Genet. 2015, 47, 410-415. [CrossRef]

66. Carvalhais, L.; Henderson, J.; Rincon-Florez, V.A.; O’Dwyer, C.; Czislowski, E.; Aitken, E.A.B.; Drenth, A. Molecular diagnostics of banana Fusarium Wilt targeting secreted-in-xylem genes. Front. Plant Sci. 2019, 10, 457. [CrossRef] [PubMed] 
67. Kearse, M.; Moir, R.; Wilson, A.; Stones-Havas, S.; Cheung, M.; Sturrock, S.; Buxton, S.; Cooper, A.; Markowitz, S.; Duran, C.; et al. Geneious Basic: An integrated and extendable desktop software platform for the organization and analysis of sequence data. $J$. Bioinform. 2012, 28, 1647-1649. [CrossRef]

68. Leslie, J.F.; Summerell, B.A. The Fusarium Laboratory Manual; Blackwell Publisher: Oxford, UK, 2007.

69. Huelsenbeck, J.P.; Ronquist, F. MRBAYES: Bayesian inference of phylogenetic trees. J. Bioinform. 2001, 17, 754-755. [CrossRef] [PubMed]

70. Stamatakis, A. RAxML Version 8: A tool for phylogenetic analysis and post-analysis of large phylogenies. J. Bioinform. 2014, 30, 1312-1313. [CrossRef]

71. Letunic, I.; Bork, P. Interactive Tree Of Life (iTOL) v4: Recent updates and new developments. Nucleic Acids Res. 2019, 47, W256-W259. [CrossRef]

72. Oksanen, J.; Blanchet, J.G.; Friendly, M.; Kindt, R.; Legendre, P.; McGlinn, D.; Minchin, P.R.; O’Hara, R.B.; Simpson, G.L.; Solymos, P.; et al. Vegan: Community Ecology Package. 2018, R Package Version 2.5-2. Available online: https://cran.r-project. org/web/packages/vegan/index.html (accessed on 23 June 2018).

73. Maechler, M.; Rousseeuw, P.; Struyf, A.; Hubert, M.; Hornik, K. cluster: Cluster Analysis Basics and Extensions. 2018, R Package Version 2.0.7-1. Available online: https:/ / cran.r-project.org/web/packages/cluster/index.html (accessed on 23 June 2018). 